\title{
Roman commercial networks in the eastern Pyrenees in the Late Republic and Early Empire: A cost analysis of the transport of imports and exports*
}

\author{
Alan Ward Koeck ${ }^{1}$
}

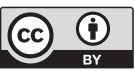

Received: $21 / 01 / 2020$

Accepted: 29/11/2020

\begin{abstract}
A computer model of the transport network in the eastern Pyrenees is drawn up, in association with a mathematical model of cost and speed of various means of transport and types of via. Results of these models include optimum routes for imports and exports to this region, and a breakdown of costs and transport times in each direction. The role of the port of Ruscino is noted in making Cerdanya and Iulia Lybica accessible from the sea, due to the higher cost of road transport in comparison to sea and river. So is the economic feasibility of the transport of merchandise such as imports of wine and exports of pernae ceretanae in relation with other regions of the Roman world, or quarried stone and salt between the region and neighboring regions in the central Pyrenees. The topic of a mountain range as a barrier to commercial activities is thus questioned.
\end{abstract}

Keywords: Pyrenees; commerce; network; Roman Empire

Resumen. Redes comerciales romanas en los Pirineos orientales durante la república romana tardía y principios de la época imperial: un análisis de costes del transporte en importaciones y exportaciones

Se presenta un modelo informático de la red de transportes en los Pirineos orientales, asociado a un modelo matemático de costes y velocidades para cada medio de transporte y tipología de via. Sus resultados incluyen rutas óptimas para las importaciones y exportaciones de esta región, así como un desglose de costes y tiempos de transporte en ambas direcciones. Se señala el papel del puerto de Ruscino para hacer accesibles la región de Cerdaña y la ciudad de Iulia Lybica desde el mar, ateniendo al precio superior del transporte viario en comparación al fluvial o marítimo. Se concluye con la viabilidad económica del transporte de mercancías de esta región en conexión con otras partes del mundo romano como sucede, por ejemplo, con las importaciones de vino y las exportaciones de pernae ceretanae, así como con las zonas vecinas del Pirineo central con el comercio de piedra de construcción ornamental y de sal. De este modo, se pone en duda el tópico de la cadena de montaña como una barrera frente a las actividades comerciales.

Palabras clave: Pirineos; comercio; red; Imperio romano

\footnotetext{
* Software developed for this project and all data generated are publicly available through the following link: <https://github.com/alanwardubuntu/xarxes>.

1. Independent researcher. awardk@gmail.com.
} 

of the transport of imports and exports

Ward Koeck, Alan. «Roman commercial networks in the eastern Pyrenees in the Late Republic and Early Empire: A cost analysis of the transport of imports and exports». Treballs d'Arqueologia, 2020, núm. 24, p. 211-243. DOI: 10.5565/rev/tda.110

\section{Introduction ${ }^{2}$}

In the context of the Iberian Peninsula during Roman times, it is perhaps natural to consider mountain ranges such as the Pyrenees as obstacles that needed to be coped with in some form. Moreover, regarding the previous period of the Punic Wars, classical sources such as Polybius (Histories) cite both the Pyrenees and the Alps as important obstacles for the progression of Hannibal and his army. By the time of the Late Roman Republic and Early Empire, the expansion of the Roman sphere of influence was confronted with this difficulty from an economic or commercial standpoint. In places, sea routes were found as an alternative means of connecting the diverse parts of the Roman world. Thus, navigation across the Tyrrhenian Sea and Gulf of Lion was an expedient means of accessing the south of Gaul and the Iberian Peninsula from Italy. However, regions situated further inland have long been considered by modern scholars as something of economic backwaters.

However, factual elements collected recently contrast with this classical vision of the Pyrenees as a barrier. Archaeological finds from successive campaigns in the Roman city of Iulia Lybica (modern Llívia, Catalonia) show that the Cerdanya region cannot be considered an isolated area during our period of interest. This is indicated by imported items such as oil and wine containers (Campillo and Mercadal, 1997), as well as decorative and construction elements made of marble originating from other regions of the Pyrenees (Guàrdia et al., 2017; Guàrdia et al., 2017). Even as far back as the Neolithic period, investigation in the nearby Vall del Madriu (Andorra) by J.M. Palet and his team has described a continuous presence of pastoral activities associated with metallurgy and forestry activities such as the production of pitch in large quantities (Orengo et al., 2013; Palet et al., 2017). Items such as hand axes made out of materials not sourced within this region have been dated from the fifth millennium BCE (Martinez et al., 2017). Some authors report an "intensification of human presence above 2000 a.s.l. from the mid IV millennium BCE” (Gassiot, 2018: 73).

During the Late Republican and Early Imperial Period, Roman presence in the Iberian Peninsula would have been felt more intensely with the interventions of Pompey, Julius Caesar and - specially - Augustus. Military presence has way to the more pacific activities of agriculture, mining and commerce. However, all these would have needed to be connected in some way to the rest of the Roman economy, both for the importing of goods necessary to sustain military garrisons and catering luxury items to the more affluent of local populations, and for ex-

2. The author wishes to thank Oriol Olesti for his helpful comments regarding this work. 
porting local produce such as the iron - a production that seems to have increased over large areas of the Pyrenees from the 2nd c. BCE (Olesti and Mercadal, 2017: 36). This opens up the possibility of existing trade routes through these mountainous regions connecting the Iberian Peninsula to continental Europe.

In this work, our first aim is to determine which itineraries towards the north or the south of the Pyrenees would have been most adequate for the purposes of transport. The case of imports and exports will be considered separately, since the end-points of such itineraries need not be the same in either case, nor the means of transport used. In the second place, we wish to draw up a transport cost profile, to assess the influence of such costs on the viability of importation and exportation from the Pyrenean region, as a function of the total distance from producer to market.

To do so, we will first consider which merchandise would have been suitable for import or export from the Pyrenean region. Then, we will set up a computer model of the transport network of the period, as we know it. We will then build a mathematical model of the various means of transport available, and of their associated characteristic speeds and costs. Finally, analysis will be performed of several typical use-cases both for imports and for exports, and the results discussed in relationship to the general economic activity of the Roman area.

\section{The merchandise}

Over the last some thirty years, a certain number of significant results have been obtained regarding imports of merchan- dise into the Pyrenean region. Just in the Iulia Lybica archaeological site, ceramics have already been published since, at least, 1996. Imported items found at the area of Cal Doctor came from Tarraconense, Narbo, the hinterland of Emporiae, and even further abroad (Campillo and Borràs, 1996). They consist of amphorae destined for the transport of garum, Dressel 7/11 type amphorae that originated from Baetica, and similar amphorae from Tarraconense, among others. Ceramic pieces dedicated to domestic use are also represented, with items "bearing white slip and reddish paint" which could have been produced either locally or imported from nearby regions north of the Pyrenees (Campillo and Mercadal, 1997). During excavations of a wide space in the center of the city of Iulia Lybica which has been identified as the Roman forum (Carreras et al., 2014), not only have ceramics been found but also construction materials (Guàrdia, 2018).

Items of some importance are stone building materials, some of which are made of marble from other regions of the Pyrenees: white marble from the quarry at Saint Béat (higher course of the Garonne river, modern Occitanie, France) (figure 1), both red and green marble

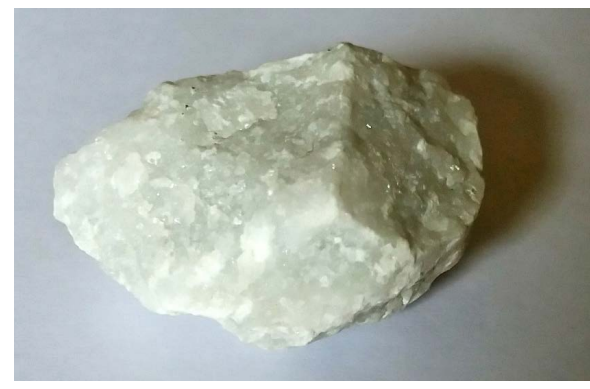

Figure 1. A fragment of white marble from the quarry at Saint-Béat. 
from Campan (Hautes-Pyrénées, Occitanie, France) (Guàrdia, et al., 2017). Some products may be identified as "exotics", such as a fragment of crustae in pavanazzo stone from Afyon (Turkey), a possible fragment of granite from Assuan (Egypt) and marble from Portassanta (Chios, Greece) (Guàrdia, et al., 2017). Their typology is rather similar to materials described in the forum of Ruscino (Perpignan, France) (Rébé et al., 2009).

As for alimentary practices, materials found in Cerdanya are comparable to those found in the Roman port of Irún (Peña-Chocarro and Zapata, 2005), specifically as regards the presence of items to which a southern Iberian origin may be attributed.

Thus, imported materials can be classified as:

- Alimentary products for the use of local communities and/or Roman residents: cereals, olive oil, wine, and garum. These products are characterized by having been transported in relatively heavy pottery recipients (amphorae). Most - but not all seem to have originated in Baetica and Tarraco.

- Ceramics used as such (in contrast to being used primarily for transport purposes), some of which is fine in nature. Some of these items were produced in southern Gaul, but others in the north of Africa. The difficulty with the transport of these items would not have been so much their weight, but rather ensuring safe arrival of these rather delicate items.

- Building materials. Even though most building materials found on site are clearly of local origin (granite and schist), some items were import- ed mostly - as far as the current inventory indicates - from quarries in the central Pyrenees, but with some items coming from further abroad and even the eastern Mediterranean area. These pieces tend to be rather small as regards building materials, and concentrate on elements of ornamental nature. This is coherent with the cost and difficulty that the transport of large stone pieces would entail.

In the opposite direction, some local production may have been suitable for export to other regions of the Roman world. Among this, gold from the Roman mine at Bolvir/Guilleries d'All that was obtained using the ruina montium technique (Morera et al., 2017) would have been an excellent candidate. However, such an export activity has not been detected in physical remains, and the volume would in any case have been low. Other mining produce could have been iron from Castellot de Bolvir (Cerdanya) (Morera, op. cit), or Goleró (Alt Urgell). In this second possible mining area, radiocarbon dating "suggest metallurgic [iron-working] activity beginning in the early 1 st c. CE", in agreement with an intensification of associated activities such as herding, pitch and pine charcoal production (Palet et al., 2017). To the north, charcoal and pitch production have also been documented in Vall del Madriu (Andorra) (Palet et al., 2006; Orengo et al., 2013). The synergy between charcoal production and metallurgy is striking, and is consistent with the large amount of charcoal needed for the production of metal. However, is it difficult to follow the continuity of their production up to modern times due to the lack of written 

of the transport of imports and exports

documentation before the 15 th c. CE (Gascón, 2013).

Pitch production during the Roman period may be seen as specially interesting, for its application as a marine hull caulking material (Marlier et al., 2014), and also as a means of sealing and making water-tight amphorae for the transport of cereals and wine, though this technique was not extensible to oil recipients (Capelli et al., 2017). It has been noted that pitch production may be considered a specialty of mountain regions, in which materials were abundant (Orengo et al., 2013). Managing the production of metals and other merchandise in the Roman period may be related to the establishment of new cities or colonies such as Lugdunum Convenarum (Saint Bertrand de Comminges, Occitanie, France) in the Pompeian (Lanz, 2017) or the Augustan periods, in both cases with a possible aim to organizing taxation (Griffiths, 2013).

Finally, produce from pastoral activities with livestock such as sheep and goats in the form of cheese, or swine (salted ham) has been documented both in the Madriu valley and in Cerdanya, where the pernae ceteranae were a product known in other regions of the Roman world (Olesti, 2017).

Thus, local produce of the Pyrenean region suitable for export may be classified as:

- Metals. Some, such as gold and silver, would have been relatively easy to transport, due to the small volume produced. As for iron, the ease of production in other regions and their relatively lower value would seem to make exporting iron a less attractive proposition. For this reason, we consider the production of iron to have been aimed in the first place at satisfying the needs of the local population, and perhaps also those of Roman military forces stationed in this region.

- Forest produce. Pine charcoal would have been used for the production of iron, but perhaps also for domestic needs. As is the case for iron, it would seem difficult to postulate an economic rationale for its export to other regions of the Roman sphere of influence. On the other hand, exporting pitch would have been expedient, to areas in which there was either shipbuilding activity, or the production of a large number or pottery recipients for holding cereals or wine. In this sense, Tarraconense and, perhaps, Laietana would seem to fit the bill quite nicely due to their wine production already well documented in Roman times.

- Livestock produce. The main items suitable for export would have been products conditioned in such a way to keep for a long period, such as cheese and salted ham or other forms of preserved meat.

As concerns the latter point, it is interesting to note that producing both cheese and salted meat consumes a certain amount of salt, which is also necessary for the herding activity itself. This must have been imported into the region, which leads us to the view that circuits for importing and exporting goods may not be considered in isolation from each other, but must be seen holistically as parts of a complete economic system covering the geographic region of interest as well as neighboring regions. 

of the transport of imports and exports

\section{The transport network}

Transport networks are typical of a subject in which the techniques of various disciplines may be brought into bear, going from topology in Mathematics to the use of Geographical Information Systems (GIS) at the frontier between Computer Science and Geography. These tools and techniques have been applied by investigators to the whole of the Roman Empire, especially by the ORBIS Project (Scheidel, 2015). Depending on the availability of data, some regions have necessarily been more precisely modeled than others. On a more local scale, detailed information has made possible the computer representations constructed of the Roman road network of Britannia (Dicks, 1972; Carreras, 1994). As regards the Iberian Peninsula, the Roman road network of Catalonia has been analyzed on its own (Soto and Carreras, 2006), and integrated within an ensemble view of the Peninsula (Carreras and Soto, 2010).

Building a computer model of such a network requires consideration of network edges, and of individual nodes. Segments need to be placed in correspondence with their real situation on the terrain. However, knowledge of Roman ways may be fragmentary: well-established in coastal areas where remains such as roadbeds, stelae or other elements of civil engineering can be identified, the task is more complex in mountain areas due to two factors. The first is that material Roman presence may have been lesser in intensity, with smaller constructions. The second is that in many areas the topography leaves little choice of where the way should pass. Thus, in situations such as a narrow river valley or a mountain pass, later constructions and engineering solutions will most likely have covered and replaced completely whatever Roman construction may have taken place. Documentation is also lacking.

Thus, in defining our network edges, emphasis will be placed on choosing placement based on likelihood more than actual information. In many cases, the situation of river valleys where transit can easily take place collaterally to the course of a river, or of mountain passes that present less material difficulties than others (perhaps a lower altitude, or a lesser gradient both for the upwards and for the descending paths) will guide our choice.

As an example, we know of the existence of the Roman Strata Ceretana, between the region of Ruscino near modern-day Perpignan, Iulia Lybica in Cerdanya, and the lower Segre river valley (figure 2). It is clear that the presence of

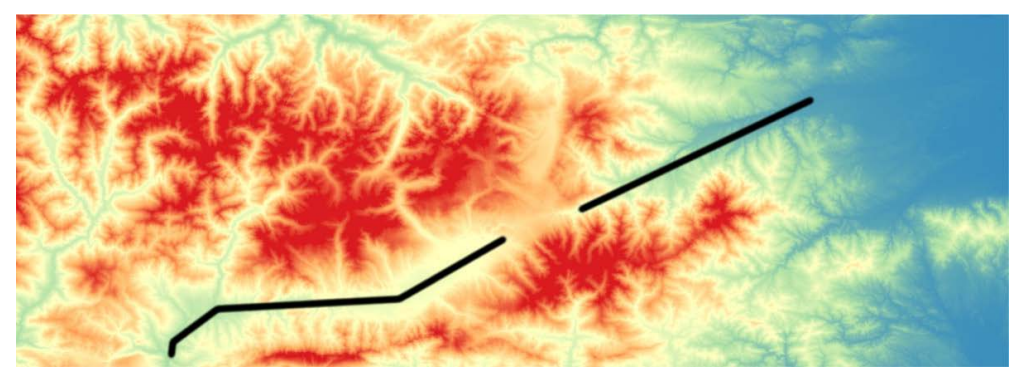

Figure 2. The Strata Ceretana, connecting the valleys of the Tet and Segre rivers. 

of the transport of imports and exports

two deep valleys - the Tet and Segre rivers - facilitated crossing the Pyrenees mountain range, as these valleys cut across most of the major geographical difficulties. There did remain one more difficult passage to connect both valleys. Then as now, the Col de la Perche is a wide, relatively accessible mountain port whose low altitude in comparison with others allows an easy transit from one valley to the other. This is a suitable candidate for the passing of commercial and military traffic in Roman times.

Another technique that may be used depends on some knowledge of existing Roman establishments, such as stationes or mansiones. Daily distances traveled during Roman times may be estimated at around 25 to $35 \mathrm{~km}$, perhaps slightly less in abrupt terrain. Thus, one can expect an itinerary to have been chosen in such a way to be easily broken up into daily segments. Thus, on the higher Segre river, establishments that are known or reasonably supposed ${ }^{3}$ to have been in existence in Roman times are located at distances within this optimal range (table 1). This helps locate probable points on which to posit the location of network edges.

Other vertices that must be included in the network are especially interesting establishments or cities, either due to their dimensions and importance, or because of their role as known military or administrative centers. Iulia Lybica has been mentioned as an administrative center. If we take into account the dimensions of its Forum, it must also have had a specific role to play in commerce. Close-by, the Castellot de Bolvir seems to have combined an economic role, with
Table 1. Distances between probable points of Roman presence along the upper Segre river valley

\begin{tabular}{llc}
\hline From & To & $\begin{array}{c}\text { Distance } \\
(\mathbf{k m})\end{array}$ \\
\hline Coll de Nargó & La Seu d'Urgell & 24.2 \\
\hline La Seu d'Urgell & Bellver & 26.4 \\
Bellver & $\begin{array}{l}\text { Iulia Lybica } \\
\text { (Llívia) }\end{array}$ & 20.5 \\
\hline
\end{tabular}

that of a military point of presence and even for tax collection (Morera et al., 2010). In the Urgell region, the central position in relation to the meeting point of the Valira and Segre rivers, and accessibility to many valleys that join the main Segre course in this vicinity (Valls de Valira, Andorra, Vall de Sant Joan, Vall de Castellbò and Valls d'Aguilar) indicate this must have been a place of some significance for commerce, even if we cannot be sure where the main establishment was sited at modern-day Castellcuitat or at la Seu d'Urgell.

Further north, the Puig d'Enclar site close to Andorra la Vella (Andorra) has also given some clues on Roman presence during our time frame. Coins dated from the third c. CE (by emperors Galienus, Magnus Maximus and Honorius) (Canturri et al., 1985) indicate the presence of commercial ties with the Roman world. More evidence would be needed, however, to obtain an idea of the size of commercial traffic. It is also open to question whether the movement of goods went across the Pyrenees, or whether it was mainly concerned with the export of local production such as pitch from the Madriu valley area.

3. The town of Organyà is not included in this series, since it is a known foundation from the Medieval period. 

of the transport of imports and exports

North of the Pyrenees, one site that would seem to have a special significance from a transport and commercial point of view is Lugdunum Convenarum (Saint Bertrand de Comminges, Occitanie, France). Besides the possible Celtic origin and later medieval occupation of the site, the Roman city and forum area are perfectly identifiable. Possible remains of a Roman military camp and of an amphitheater have been described, and also and this is significant for our purposes - those of a port on the river (Esmond-Cleary, 2008). The city is placed at a natural intersection of routes. The higher course of river Garonne allowed easy transport to Lugdunum of the produce of the Pyrenees, such as marble from the quarry at Saint-Béat. This same river facilitated transport downstream to Tolo$s a$ and its own river port, as well as access to river Ariège and also access to the Roman road network towards Narbo (modern Narbonne, on the Mediterranean coast) and Burdigala (modern Bordeaux, on the Atlantic Ocean). Finally, a secondary route granted access to modern Béarn region, with some importance due to its production such as, among others, red and green marbles from the quarry at Campan.

Very many other sites of commercial significance may have existed in Roman times that have been lost due to lack of material evidence.

Most Roman roads in modern Catalonia are rather well-known (Soto, 2011), as are those of the Iberian Peninsula as a whole (Soto and Carreras, 2006). The complete network of the Roman has been studied, for instance by the ORBIS project (Scheidel, 2015). Major arteries would have had the characteristics of a via munita, with a hard stone surface.
A second category, however, would have consisted of ways used for local transport, for instance for farms in agricultural zones to bring their produce to market. Equivalent to the cami ral of preindustrial times in the Iberian Peninsula, these non-surface routes would have often been situated by the side of rivers, following their valleys. Thus, steeper grades would have been avoided, and reasonably loaded vehicles would have passed even over these rougher surfaces. These via glareata or terrena would have been the responsibility of local populations and their authorities. Over the centuries, the transport needs of main agricultural centers would not have changed overly, meaning these local routes would have been kept until medieval times or later, and in many cases covered by the modern secondary road network.

Finally, a third type of terrestrial route would have been the mountain path. By nature, these ways do not typically allow passage of wheeled means of transport. Thus, traffic would have been limited to that of people (in limited numbers), pack animals such as donkeys and mules, and such commercial transport as could have been carried out with these means. As for military uses, only smaller units could have transited over these routes with any ease, and perhaps also military or administrative post.

Another type of route that merits attention is waterways. Fluvial transport has been widely documented from Roman times, such as in Lugdunum Convenarum. It is no surprise that many urban centers of the time were sited either on seacoasts, or in places where a large river allowed easy access to inner land areas. Wellknown examples include Rome and the Tiber river, Arles and the Rhone and, in 
closer proximity to our geographical area of interest, Ruscino and the Tet, Emporiae and the Fluvià, Baetulo and the Besòs, Barcino and the Llobregat, or Amposta and Tortosa both on the Ebro.

There is, however, a difference to be made from the standpoint of water transport between wide rivers in the plains, and the smaller and more impetuous mountain rivers. These are not always usable as a waterway during the whole year, due to variations in water flow with periods of low levels at the end of summer and early autumn, as well as periods of abundance or even excess making naviga- tion dangerous when rainfall is especially abundant (late autumn) or the snows melt in the spring. Rivers in steep terrain also present differentiated characteristics for navigation in either direction. Downriver, the water itself can often supply all the motive force needed, and boatmen will merely need to correct course as necessary. Upriver, on the other hand, is difficult or even impossible on narrow courses where sails are often of little practical use. This dichotomy of direction of navigation has its effect on the economy of water transport. Optimal routes in one direction or the other may have resulted

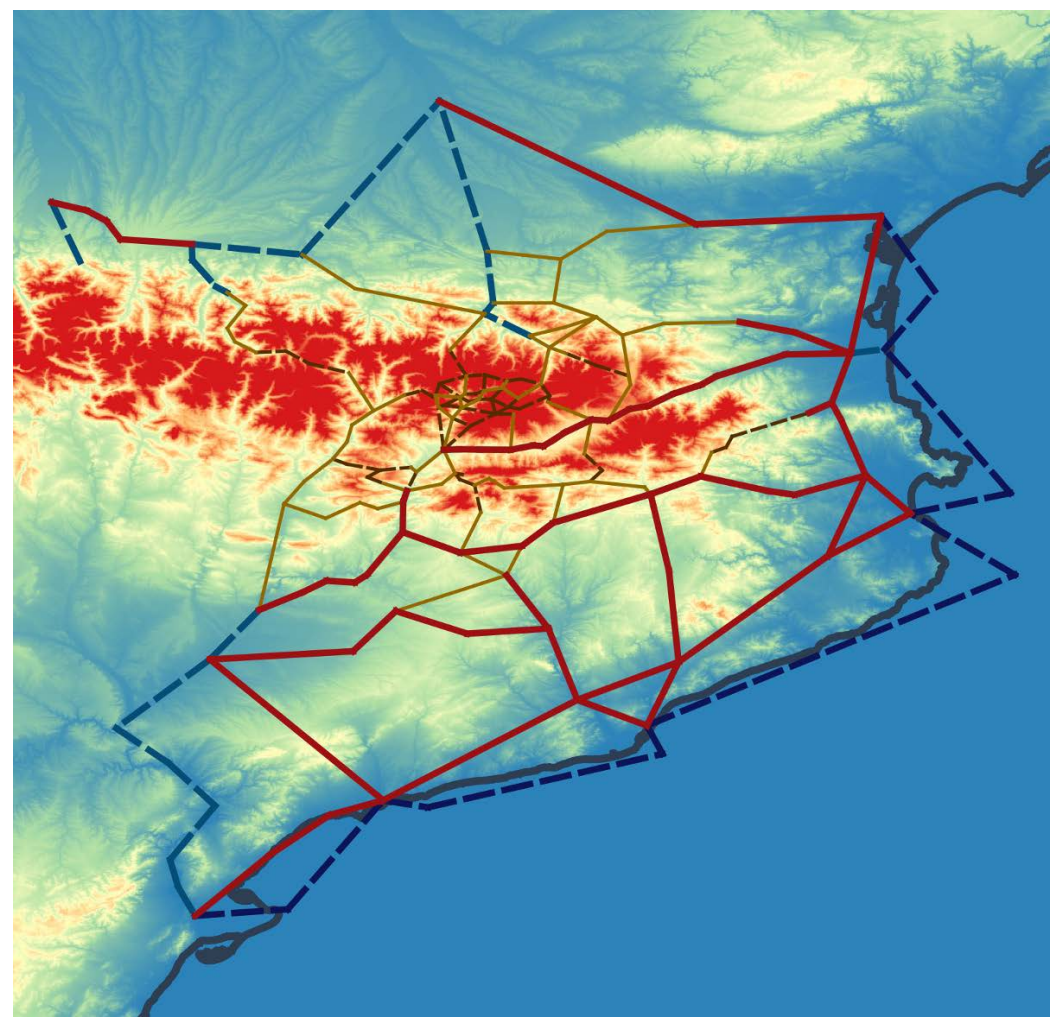

Figure 3. The network used in the computer model: main viae in red, secondary roads in brown, mountain paths in black, and sea and river routes in shades of blue. 

of the transport of imports and exports

in a combination of segments done by terrestrial means, or by river navigation that were not the same in itineraries taken from the coastal area up to the Pyrenees (imports towards the mountains, in our study), or other taken from the mountains down to the sea (exports in our sense).

Sea navigation may also be an important part of a complete study of transport in our area. There were, obviously, no sea routes crossing the Pyrenees. However, since we shall see that sea transport was one of the more economical means available in Roman times, ports such as Ruscino, Emporiae or others must have played an important part in connecting this geographic area to the rest of the Empire. In these, also, meteorological aspects must be noted such as the large-scale closing of sea routes in the Mediterranean during the winter to avoid losses of ships and their cargoes during winter storms.

The network thus constructed is presented in figure 3. It may be noted that detailed coverage has been included mainly of the specific area of interest; while main terrestrial, fluvial and sea roads are included for a larger area due to their importance for imports and exports from other regions of the Roman sphere, secondary roads and mountain tracks are supposed to be pertinent only at a more local scale.

\section{Means of transport}

Once the transport network has been drawn up, we now need to consider the means of transport available in Roman times, and their characteristics as regard speed, and costs. The work of several teams - such as Carreras and Soto - is based on the Edict on Maximum Prices of Emperor Diocletian (Diocletian, 301). This model is, however, based on transport through terrain that is considered globally, without making a difference between the flatter parts of an itinerary and other routes that may show more or less steep sections. As for river transport, these models do discriminate between up- and downriver transport, both as regard speed and cost per unit of distance.

In a more recent work (Muńoz, 2018), a more complex model of transport characteristics has been drawn up as a function of slope, though it was proposed in relation to a very specific study case in which the presence of predetermined types of roadway was not applicable. A more complete model may need to consider not only slope, but also road types and surfaces, means of transport and even weather factors. These latter seem to have been little studied up to now, but may be of logical importance when our interest centers on routes over high passes such as the Col de la Perche situated on a major Roman via between Ruscino and Cerdanya.

In any case, the relationship between road types and the means of transport that could use each type is clear: a carruca could hardly pass through a steep mountain pass that a pack animal such as a donkey or mule could have negotiated with ease. On flatter stretches of a wellpaved via, the use of heavier vehicles harnessed to oxen would have eased the transport of heavy loads, though at a slower pace. Several combinations of water transport are also probable, be they on fluvial, coastal or high sea vessels. For this reason, some elements that need to be taken into account to classify network edges are: 
- Terrestrial road segments, comprising main paved roads, secondary roads unpaved but with sufficient width to allow the passage of wheeled vehicles, and finally mountain paths.

- River routes that have different characteristics in either direction. Some mountain rivers would - then, as nowadays - have been useful only downriver.

- There are obvious limitations related to climate, such as terrestrial routes with high passes that would have been passable only during summer and fall, but closed to all traffic during winter and spring. This is also the case of river transport, which depended on a suitable flow of water.

In the previous figure, main roads are depicted in red, secondary roads in orange, mountain tracks in black, and water transport in blue.

Iconography may help in determining types of traffic on terrestrial routes, though types of conveyance used in highclass social contexts - such as the Vestal Virgin's carpenthum in Rome itself - are perhaps better described in sources that would be more rustic vehicles used for commercial purposes in this more modest region of the Roman sphere of influence. With this said, we can reasonably suppose that vehicles accessible to transporters would have comprised carts following Roman (such as the carruca) or even Gaulish patterns, with one or two axles in function of the specific application. These vehicles would have been limited to main and secondary roads. On mountain paths, with their steeper grades and an inverse dependency between slope and vehicle speed, the means of transport of choice would have been pack animals and specif- ically donkeys and mules - these latter used in both civil and military contexts. Unfortunately, specific details such as preferred species have not been recorded for the Pyrenees and must, pending further data, remain open to speculation.

As for river transport, finds such as those documented in (Marlier, 2014) give us insight on types of vessel - such as barges - used on larger rivers. However, the lack of depth, narrow course and the existence of rocks in mountain rivers mean that large types of vessel must be excluded in our geographical context, except for specific rivers such as the Ebro. On most rivers in the Pyrenees, it seems more reasonable to posit the use of rather small boats, possible of local types and construction.

Another possibility would have been the technique of floating goods directly. Rafts to float bulk wood downriver were commonplace to bring this typical Pyrenean produce down to the coast, as late as the early 20th c. CE. The materials used were easily obtained in Roman times and, in our thought, there is no reason not to suppose the use of this technique in Roman times, even though material proof would be difficult to obtain.

Finally, sea transport would have used typical Roman vessels of the time.

Calculating the cost and speed of each means of transport presents some challenges, related both to the diversity of types of draw and pack animals, and the speeds these means of transport could sustain in function of their load and the type of way available.

Previous proposals to model these elements began with simple models, such as dispensing with terrain steepness and modeling each type of transport using an average speed not dependent on its load or distances covered. Thus, we had: 

of the transport of imports and exports

$$
\begin{gathered}
\text { time }=\text { distance } / \text { speed } \\
\text { cost }=\text { distance } . K
\end{gathered}
$$

Here, $\mathbf{K}$ a fixed cost per unit of distance covered for each means of transport. Magnitudes may be expressed in any convenient system. In this linear model proposed in (Carreras, 1994) and followed by (Soto, 2010), values of $\mathrm{K}$ and speed are based on Emperor Diocletian's Price Edict (Diocletian, 301). It is, no doubt, an acceptable approximation for the calculation of transport times and costs when the terrain is relatively flat, and as an average over long distances. However, it does present some difficulties for our study area, since we consider difficult terrain where changing slope values have an impact on vehicle speed, and therefore on transport time and cost.

A model proposed in (Herzog, 2003) and applied in (Fonte et al., 2017) is:

$$
\text { relative_cost }=1+(s / \sigma)^{2}
$$

Here, $s$ is the slope of the way and $\sigma$ the critical (maximum) slope accepted by a specific means of transport. Both are given as percentages, and authors propose typical values of $\sigma$ between 8 and $16 \%$. This model has the advantage of taking slope into account, and may be further elaborated. In (Muñoz, 2018), a similar model using an exponential function is proposed, using:

$$
\text { time }=\mathrm{A} \cdot \mathrm{e}^{\mathrm{B} \cdot|\mathrm{s}|}
$$

Here, $A$ and $B$ are constants related to each type of vehicle, which in the study cited are military units of infantry, cavalry, chariots and elephants.

However, this type of model also has some drawbacks, such as:
- Negative slopes are not treated, so the excess cost of handling a steep descent, which may or may not be symmetrical to the excess cost of going up a similar incline, is not represented by the mathematical formula.

- There is no clear casual relationship between the mathematical form of the equation, and the physical underlying phenomenon.

- Calculating a correspondence between travel time and its cost was not pertinent for the purposes of the work cited; whose aims were the analysis of the movements of Hannibal's army through modern-day Catalonia at the beginning of the Second Punic War.

To supplement these aspects, our proposal is the following:

$$
\text { time }=\text { distance } / \mathrm{V}_{\mathrm{H}}+\mid \text { height } \mid / \mathrm{V}_{\mathrm{V}}
$$

Here, distance is the horizontal distance covered over a specific network edge, while height is the difference of altitude. For ease of conversion, standard modern units are used: meters and hours. For each means of transport, an average speed is defined both in the horizontal plane $\mathrm{V}_{\mathrm{H}}$, and vertically $\mathrm{V}_{\mathrm{V}}$.

This outlook is coherent with a physical analysis. Each means of transport had a certain power output, lower in Roman times than for modern vehicles with internal combustion engines, but still a limiting factor for their performance. Horizontal movement requires the expenditure of a certain amount of energy per unit of distance, which at the low speeds of animal-drawn vehicles may be supposed more or less constant for a par- 

of the transport of imports and exports

ticular set of load, vehicle characteristics and wheel-road materials combination. Thus, there appears a natural limit on the speed achievable by this means of transport, even on level ground. This leads us to $\mathrm{V}_{\mathrm{H}}$.

On the other hand, going up or down a slope requires the expenditure of more energy, either to draw the load uphill, or to brake the vehicle when going downwards. This limits maximum speed in each direction, in proportion to the supplementary effort required, which leads us to $\mathrm{V}_{\mathrm{V}}$.

The complete model can be seen as an extension of that developed in (Carreras, 1994) to situations where slope has a non-negligible effect. Using the same data as this author, performing unit conversions into a metric system, and taking into account suitable vehicles for each type of network edge, these parameters may be estimated (table 2).

As for cost, in (Soto, 2011) a simple distance-based linear cost function was applied. In this work, we propose to modify this approach and base cost on the time taken for each segment, rather than distance. This hourly cost function is more suitable, in our view, to situations where a day's march may cover substantially less distance going up a mountain pass, than over flat coastal ground; how- ever small the distance covered, both beasts and their human owners will still need to eat the same amount of food, if not more. So, our proposal is:

$$
\text { cost }=\text { distance } . K \text {. time / time_flat (6) }
$$

Where time is the effective duration of this segment as calculated in equation (5), while time_flat would have been its duration if undertaken over flat terrain. Both equations may be combined as:

$$
\begin{gathered}
\text { cost }=\text { distance } . \mathrm{K} .\left(\text { distance } / \mathrm{V}_{\mathrm{H}}+\right. \\
\text { |height } \left.\mid / \mathrm{V}_{\mathrm{V}}\right) /\left(\text { distance } / \mathrm{V}_{\mathrm{H}}\right)
\end{gathered}
$$

Estimating cost over the reference period covering the $1 \mathrm{st} \mathrm{c}$. BCE to the $1 \mathrm{st}$ c. CE does have the drawback of having to deal with the fluctuations in value of Roman coinage. This, combined with the fact that our reference prices are drawn from Diocletian's document of two centuries later leads us to the idea that using the value of a certain amount of the staple commodity par excellence, wheat, is an expeditious means of obtaining costs in comparable terms. Following the indications of the Edict, and applying pertinent conversions of units, we obtain table 3:

Table 2. Speed parameters for modeling different types of way

\begin{tabular}{llcc}
\hline Type of edge & Type of vehicle & $\mathrm{V}_{\mathrm{H}}(\mathrm{m} /$ hour $)$ & $\mathrm{V}_{\mathrm{V}}(\mathrm{m} /$ hour $)$ \\
\hline Main road, paved & Wheeled, animal drawn & 2000 & 500 \\
Secondary road, unpaved & Wheeled, animal drawn & 1600 & 500 \\
Mountain path & Pack animal & 1000 & 500 \\
River, downriver & Small boat, raft & 2510 & \\
River upriver & Small boat & 600 & \\
Sea & Sea-going vessel & 3700 & \\
\hline
\end{tabular}


Table 3. Cost parameter for modeling different types of way

\begin{tabular}{llc}
\hline Type of edge & Type of vehicle & K $(\mathrm{kg}$ of wheat / tonne transported / km) \\
\hline Main road, paved & Wheeled, animal drawn & 4.92 \\
Secondary road, unpaved & Wheeled, animal drawn & 4.92 \\
Mountain track & Pack animal & 4.21 \\
River, downriver & Small boat, raft & 0.33 \\
River upriver & Small boat & 0.66 \\
Sea & Sea-going vessel & 0.1 \\
\hline
\end{tabular}

As can be seen, sea transport is a natural most economical means of transport, with river transport a close second. Road transport is the most costly, as could be supposed initially. The low price of transport by pack animal over mountain tracks is coherent with the fact that the cost of the vehicle itself need not be factored in. However, disadvantages of this system included low maximum loads. It should also be noted that its relatively lower cost would have been set back by the increase in the duration of each segment covered due to slope. The end result is, realistically enough, that transport over mountain tracks would actually be more costly that the use of vehicle transport on a similar distance over flat ground.

\section{Results and analysis}

Once the computer model of the network and mathematical model of the speed and cost of different means of transport were set up, Dijkstra's algorithm to compute the shortest past in directed graphs (Dijkstra, 1959) was used to two separate sets of results. The first was a collection of optimum paths for typical imports into the Pyrenean area, with the aim of determining which itineraries were most likely to have been taken in the time frame of interest. The sec- ond result set was a mapping of minimal time and cost for exports from the region, with a view to analyzing the cost of transport and economic feasibility of such exports, to nearby regions (local exports) or further abroad to economic centers of the Empire such as the city of Rome itself.

\subsection{Importing foodstuffs}

Typical imports into the region were further divided into two categories: foodstuffs and construction materials.

In the first place, there are foodstuffs corresponding to the pottery recipients found in Iulia Lybica: wine, olive oil, and garum. The origins of these products - such as Baetica, Italy or Africa Province would imply in most cases, having transited through a sea port. Taking into account both distance and ease of connection, some options include (from north to south): Narbo (Narbonne), Ruscino (Perpignan), Emporiae (Empúries), Barcino (Barcelona), Tarraco (Tarragona) or Dertosa (Tortosa), this latter on the Ebro river. Even origins close by such as Tarraconense or Southern Gaul could have made use of these ports as a commercial center through which goods transited.

A typical example of such imports might have been, for instance, an import of foodstuffs contained within pottery re- 

of the transport of imports and exports

cipient from the port of Dertosa, with their final destination being Iulia Lybica. The analysis of this route (figure 4) gives us some insight into how cost is accumulated along such an itinerary.

Several possible choices of route would have been imaginable. Perhaps the most obvious could have been to proceed north-west along the Ebro, using river transport as an economic alternative to land up to the confluence with River Cin$\mathrm{ca}$, then proceeding upriver on River Segre to modern-day Balaguer. From there, road transport would have been required to proceed ever northwards alongside the Segre (no longer easily navigable, especially upriver) on the Strata Ceretana through Urgell and Cerdanya to reach Iulia Lybica. Another possibility could have been the use of sea-transport as the most economical means to the port of Emporiae, or perhaps Ruscino, and then proceeding overland to Iulia Lybica on the shortest route through the Col de la Perche. However, our model actually determines a third route as an optimum: by sea to the port of Barcino, and then overland through modern Vic, Ripoll, Campdevànol, and the Castellar mountain pass near La Molina to reach Iulia Lybica from the south-east.

It is worth noticing that, from a practical standpoint, this itinerary uses sea transport for over half the total distance, thus reducing cost dramatically over other choices. When terrestrial means are used, a large section of primary, main road, was available up to Campdevànol, with increasing but still manageable grade. Finally, goods would have needed to be transported by pack animals over steep mountain paths only to pass the pass at Castellar, a difficult but relatively short segment of the complete route. Following this route, the total distance covered would have been some $328 \mathrm{~km}$, in 136.7 hours, for a total cost of the equivalent of $724.9 \mathrm{~kg}$ of wheat per tonne of goods transported. Of these, the main expenditure would have been incurred on the second half of the journey, from Barcino to Iulia Lybica: $140 \mathrm{~km}$ covered in
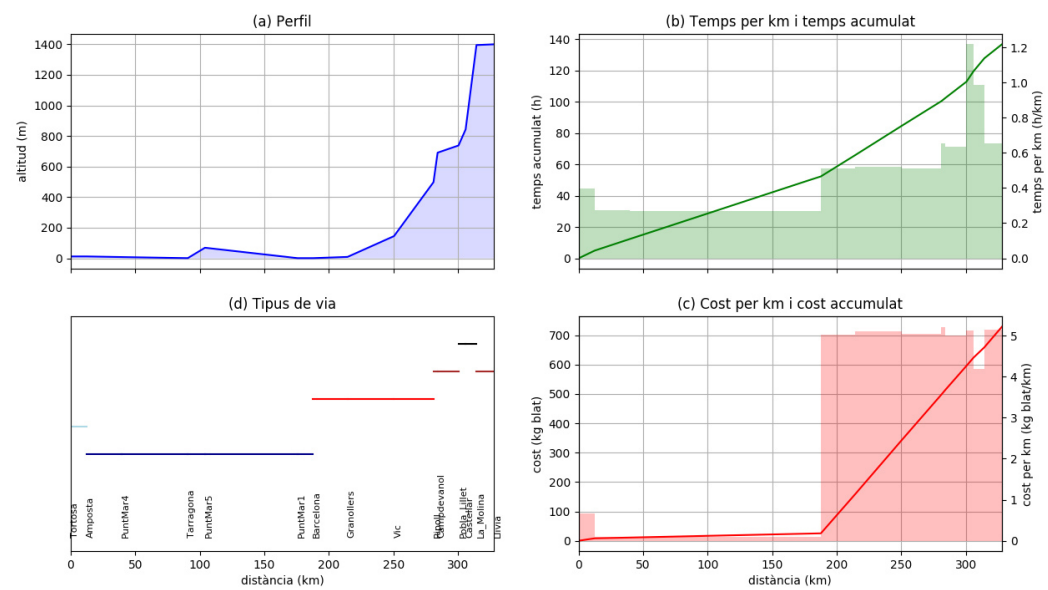

Figure 4. Speed and cost analysis: transport from Dertosa to Iulia Lybica. 
84.4 hours, for a cost of $703.8 \mathrm{~kg}$ of wheat per tonne transported.

Another interesting route is obtained when an optimum journey is calculated from the port of Emporiae to Iulia Lybica. Before performing actual calculation, a first impression gave us the idea that it must surely have been beneficial, in such a case, to proceed directly inland following the southern flank of the Pyrenean range. In fact, the computer model prefers another route, running north of the Pyrenees along the Strata Ceretana (figure 5). This choice may be analyzed in the following manner: terrestrial transport is used throughout, and thus average speed and costs are remarkably uniform - with one single exception, the segment through the Col de la Perche near its end. This relatively minor stage concentrates the main difference in elevation of the complete route within a relatively short distance, allowing the major part of the journey to take place without excessive expense.

We may also note that the cost of the journey from Emporiae is, at $791.1 \mathrm{~kg}$ of wheat per tonne of goods transported, slightly higher than that of the journey from Dertosa. However, the difference is not large enough to warrant proceeding south by sea to Barcino, and then overland to Iulia Lybica as in the previous optimum route.

In general, similar calculations using other sea-ports as the origin of our journey show that, for goods proceeding towards Cerdanya of southern origin, Barcino was the best (most economical) choice of sea-port to use in combination with a terrestrial route through Ripoll and the pass of Castellar, while for goods coming from the north, Ruscino was the most economical choice with a terrestrial route through Col de la Perche. Emporiae was sited more or less in the middle of these two areas, but fell in to the northern region by a small margin.

These results confirm the fact that, before the introduction of modern roads and mechanized means of travel, journeys through mountain terrain were considerably more costly and slower that sea jour-
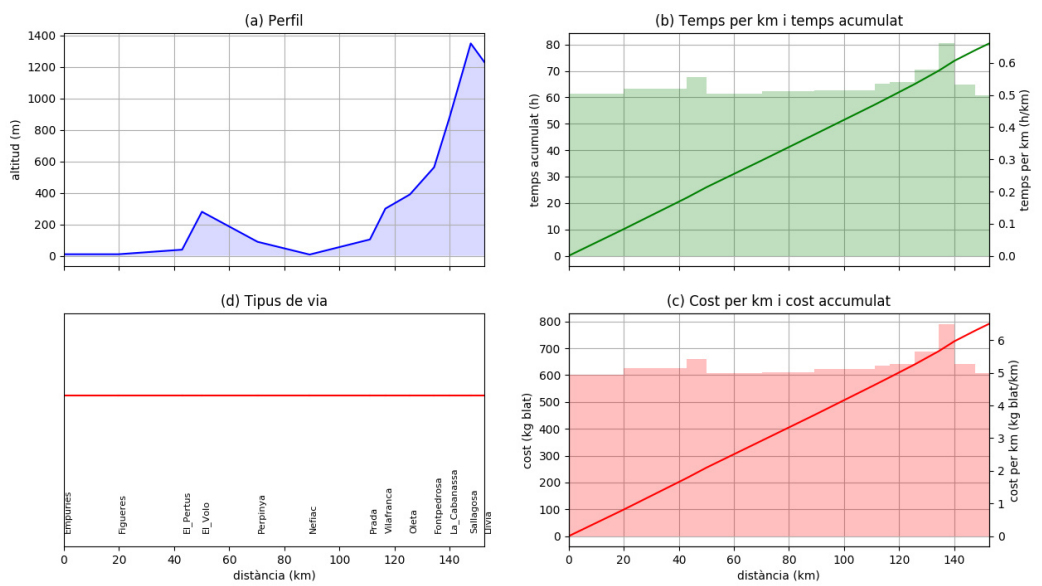

Figure 5. Speed and cost analysis: from Emporiae to Iulia Lybica. 

of the transport of imports and exports

neys. For this reason, it is clear that mercatores of Roman times would have preferred to reduce the segment of their journeys taking place using land transport to the maximum, preferring instead to rely on sea transport as much as possible.

It is striking, however, that such optimization came at the cost of complexity. In this itinerary - as in others that may be calculated using the same network the use of different means of transport following actual conditions on each segment may have required the services of various local intermediaries: shipowners and captains on the sea route, but also charters of oxen and carts for the first part of the land segment of the route, or pack animals to cross the final reaches to attain their target destination.

\subsection{Importing other materials}

In the second category of imports, sui generis goods such as construction materials seem, for some, to have origins such as Africa Province or even the Eastern Mediterranean - that would also imply import through a sea port. We will no detain ourselves with materials of such origins, since the details of their transport would have been much the same as for foodstuffs - with the caveat, however, that larger items would have been transported only with extreme difficulty of passes such as the port of Castellar and, perhaps, also the Col de la Perche.

Construction materials of other origins, however, such as marbles from the Pyrenean quarries of Saint-Béat and Campan, would have required transport far from the coast.

Saint-Béat is close to the site of $L u g$ dunum Convenatum, modern-day SaintBertrand-de-Comminges. Noteworthy is the fact that we know of the river port of this city on river Garonne, and also that the marble quarries of Saint-Béat are also situated close to the Garonne. River transport thus immediately presents itself to us as a possibility for the ease of transport of blocks of stone. However, Campan is situated much further west, and is not in the Garonne catchment basin. Any route for the transport of red or green marble items from Campan to Iulia Lybica must, of necessity, be longer and more complex than from Saint-Béat. The analysis of an optimum itinerary (figure 6) is illustrative of the effort needed.

The optimal solution for this transport problem uses river transport where possible. Thus, the first segment is downriver (on the river Adour) from Campan to the site of the modern city of Tarbes. Then, road transport must be used to cover the watershed between the basin of river Adour, and that of the Garonne. Once at Montréjeau (near Lugdunum Convenarum), the Garonne may be used to navigate downriver to Salies. As can be seen in sub-graphs (b) and (c), this use of fluvial transport results in a saving of time, but mostly of cost on these segments. From Salies onward to Iulia Lybica, the best route would follow secondary roads to Tarascon, and then through Montgaillard, Lavelanet, Campagna and Matamale, arriving in Iulia Lybica from the north. The first part of this itinerary is still a major artery in modern times; however, from Montgaillard onwards, routes than currently must be considered very minor départementale roads may have had more importance in Roman and even medieval times, a fact that illustrates changes in territorial management and transport planning over the centuries. 


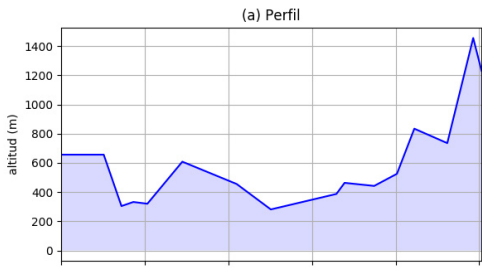

(d) Tipus de via

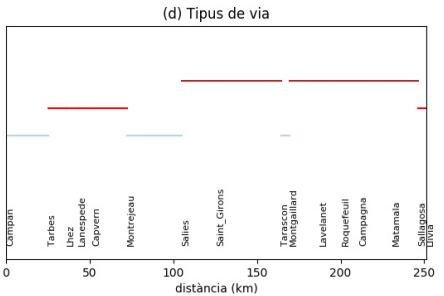

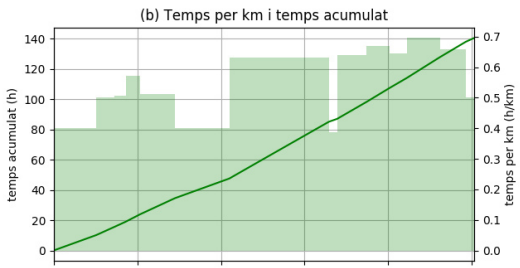

(c) Cost per $\mathrm{km}$ i cost accumulat

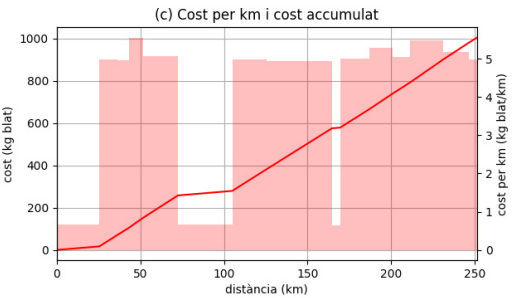

Figure 6. Speed and cost analysis: from Campan to Iulia Lybica.

As before, the complexity of this itinerary is noteworthy, as regards the amount of different means of transport used. In reality, one could expect that goods would not have been move from one means of transport to another to cover some shorter segments, as the cost of manipulation would have exceeded the saving made. Thus, after using road transport (on secondary roads) from Salies to Tarascon, and once more from Montgaillard to Saillagouse, it is probable that the stone items transported would have been left on their carts to cover the short distance between Tarascon and Montgaillard, and not transported upriver on small river vessels.

Even so, both time and effort required for this journey would have been significant, at 140.3 hours and a cost of $983.6 \mathrm{~kg}$ of wheat per tonne of goods. It is thus clear that such an undertaking would not have made sense for generic goods with a moderate value. On the other hand, a fortnight's journey for delivering high-value items such as marble cladding or crustae would certainly have been feasible. Let us note that the cost of transport of such items from the western part of the central Pyrenees is comparable to that of importing them from a sea-port such as Ruscino or Emporiae, especially, when in those cases one must add the cost of transport by sea from the place of origin of the goods.

As for transport of white marble from Saint-Béat, a further surprise awaits us (figure 7). Rationally, we could reason that it would have been best to avoid crossing high mountain passes such as those between modern Val d'Aran and the Pallars region of Catalonia when transporting stone items to Iulia Lybica. The northern route - beginning downriver to Lugdunum Convenarum - would have both the advantage of avoiding high altitudes, and of commonality with the route from Campan. But the computer model prefers another possibility: upriver from Saint-Béat to the port at Bonaigua, down to Llavorsí in the Pallars, then up once more to Tor. It would then cut 

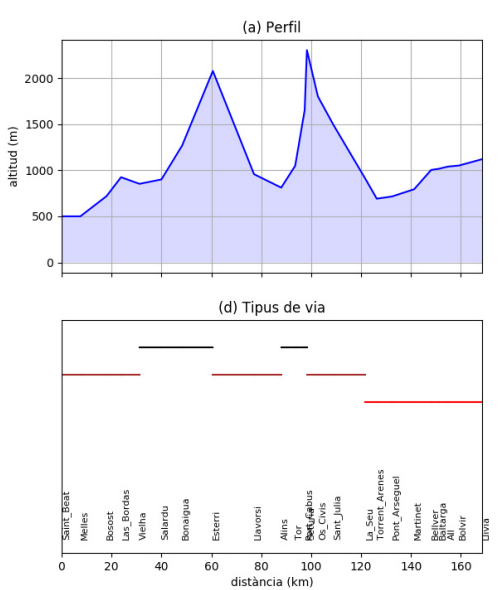
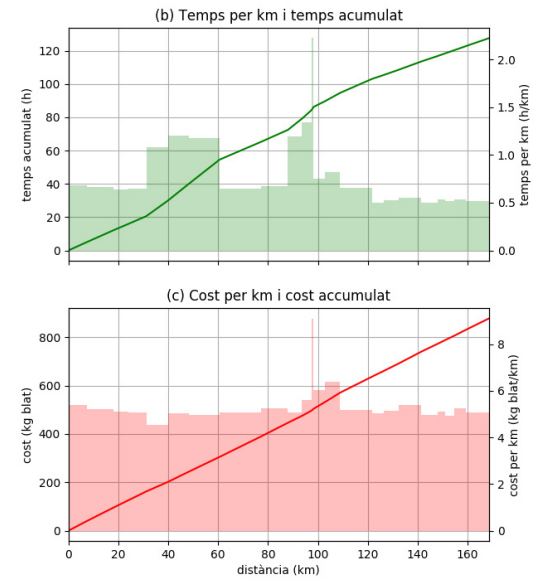

Figure 7. Speed and cost analysis: from Saint-Béat to Iulia Lybica.

through part of modern-day Andorra (Sant Julià de Lòria), and follow the Strata Ceretana up from la Seu d'Urgell to Iulia Lybica.

Specially surprising is the fact that this route would take only 127.6 hours, and come at a cost of $877.5 \mathrm{~kg}$ of wheat per tonne of goods - rather less than transport from Campan, and comparable to transport from the coastal ports of Emporiae or Ruscino.

When the route's altitude profile in sub-figure (a) is considered, we can observe that two major difficulties are encountered, one at Port de la Bonaigua between the Val d'Aran and Pallars, and the other at Coll de Cabús between Pallars and Andorra. It is here that, unsurprisingly, travel times decrease and costs increase. However, as before, the length of these two segments in relation to the complete journey is rather small, and for this reason average speed and cost of transport remains within reason.

\subsection{Exports}

Goods susceptible of being exported from the Pyrenean region would need to have two obvious characteristics: one is the ability of conservation during travel, and the other is sufficient value for transport to make economic sense. The first condition may be met by products coming from forestry or mining, such as wood, pine pitch, and metals. Products originating from pastoral activities may also be suitable, when they were processed as part of their preparation. This would be the case both of cheese, and salted ham such as the pernae ceretanae.

The first geographical center from which exports are proposed is the Madriu-Perafita-Claror Valley, in modern Andorra. As a prototypical center of mountain pastoral and forestry activities, its produce is known to have consisted of pitch and charcoal, to which it seems reasonable to add pastoral products such as cheese even though they may not be documented by findings. 
As may be observed in figure 8 , the cost of transport from the Madriu to nearby areas in modern-day Andorra, Alt-Urgell and Cerdanya is low, with values of 100 to $200 \mathrm{~kg}$ of wheat being common. Exports to these areas would thus be reasonably interesting from an economic standpoint, even for goods with relatively low values since transport costs would still remain at an acceptable percentage of the total. However, nearby regions would probably already have a production of similar goods. Further away, most areas would have been reachable at a cost of between 500 and $600 \mathrm{~kg}$ of wheat per tonne, with a noticeable low value of only 435 for the Val d'Aran. Special emphasis may be made of the cost of transport to the ports of Ruscino at 615 $\mathrm{kg}$, Emporiae at $632 \mathrm{~kg}$, Barcino at $652 \mathrm{~kg}$ and Dertosa at $608 \mathrm{~kg}$. In this last case, it may be noted that the optimal route from the Madriu to Dertosa is not the same as in the upward sense, and which passed through Barcino and El Castellar. When going downwards from the mountain to the sea, it was more advantageous to descend the Segre river valley along the Strata Ceretana, initially by road transport and then taking advantage of river transport as available on the Segre, Cinca and Ebro rivers.

When a similar calculation is made for goods exported from Iulia Lybica (figure 9), the global results are comparable, with a natural tendency of ease of transport towards the east. To the north, the regions of modern Limoux and Carcassone are easily accessible, and at reasonable cost. It is also striking that transport towards the west (Val d'Aran and Comminges) still remains at reasonable levels

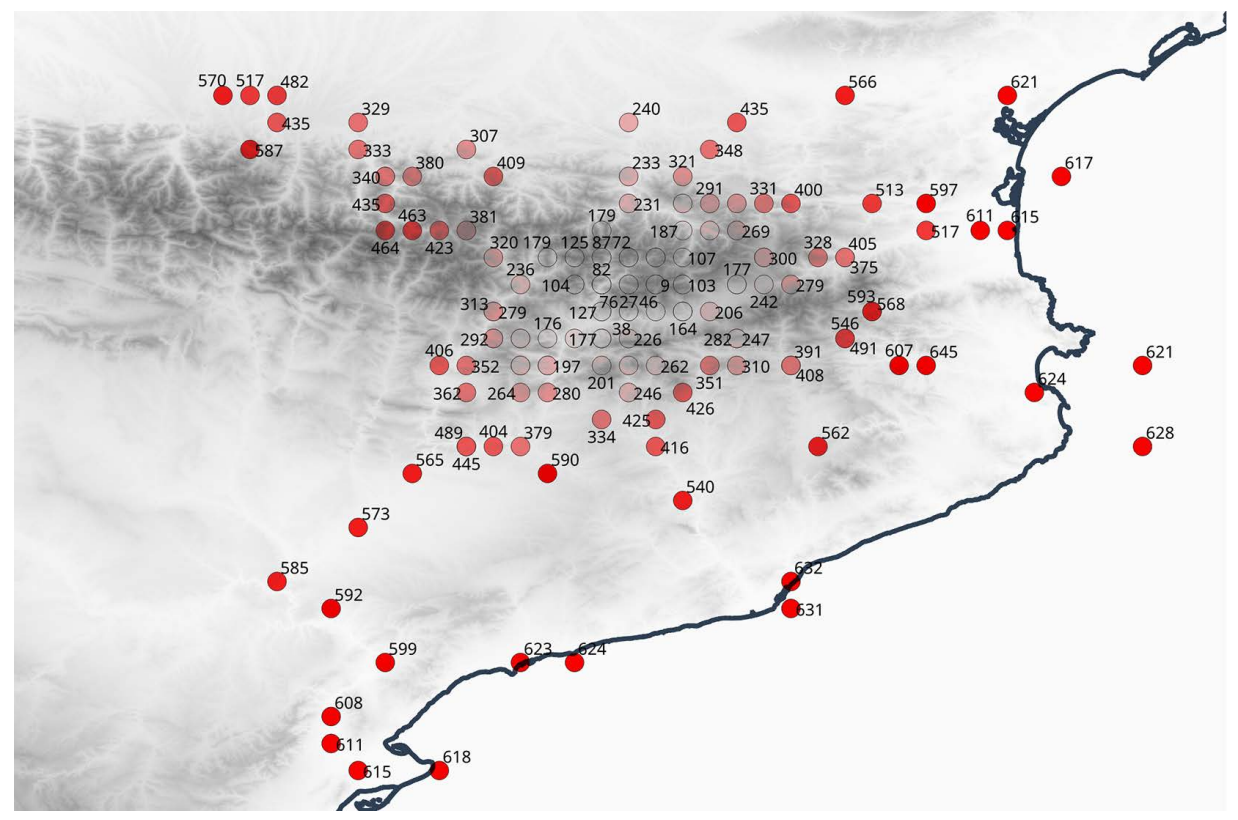

Figure 8. Cost of exports from the Madriu valley, expressed in kg of wheat per tone goods. 


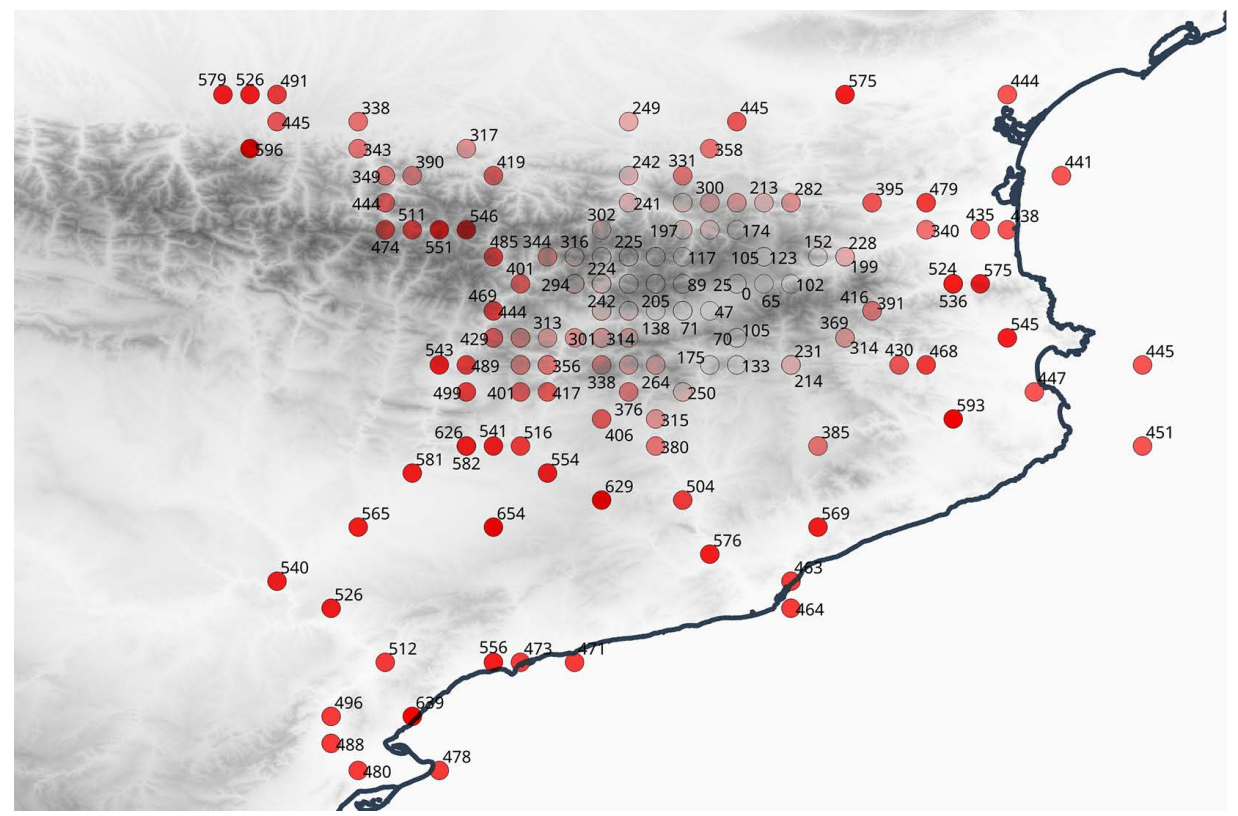

Figure 9. Cost of exports from Iulia Lybica, expressed in $\mathrm{kg}$ of weat per tone of goods.

in the range of 300 to $400 \mathrm{~kg}$ of wheat per tonne transported.

Transport to the southern ports of Dertosa and Tarraco is also facilitated, by avoiding the Segre river valley. In this configuration, optimum routes use land transport only to the port at Ruscino, and then ship goods onward by sail to other ports at Barcino, Tarraco, and Dertosa. It is thus clear that it would have made sense to use the port of Ruscino as a logistics center for any exports from the Cerdanya region and Iulia Lybica to other regions of the Roman sphere of influence.

\subsection{Interregional transport in the Pyrenees}

Though our discussion has been centered mainly on imports and exports between the Pyrenees and other regions of the Roman sphere of influence, it must not be forgotten that some commerce took place at a regional or local scale. A major candidate for such commerce may be salt. In our geographical context, it would seem that two centers of salt production existed, each with its own area of influence. One was the well-known salt mine at Cardona, known as the "mountain of salt" and which was already actively exploited in Roman times. The other was the salt pans at Gerri de la Sal in the Pallars, which has been documented since medieval times, but we think it is reasonable to suppose may have been in activity earlier.

Areas that would have been concerned by salt imports coming from these two production centers include any place where animal husbandry was of importance: salt would have been used not only for human needs, but also for those of the beasts in the form of mineral licks. The 

of the transport of imports and exports

use of salt would also have been a necessity for the conservation of pastoral products such as cheese and salted ham.

Taking, once more, the Madriu River Valley and Iulia Lybica as potential targets for salt imports, the computation model has generated results set out in Table 4:

Table 4. Cost of transport of salt from centers of produce to places of use

\begin{tabular}{lll}
\hline & $\begin{array}{l}\text { Vall de Madriu- } \\
\text { Perafita-Claror }\end{array}$ & Iulia Lybica \\
\hline Cardona & Cost: $499.4 \mathrm{~kg}$ & Cost: $379.6 \mathrm{~kg}$ \\
& Time: $68.5 \mathrm{~h}$ & Time: $53.6 \mathrm{~h}$ \\
Gerri de & Cost: $353.3 \mathrm{~kg}$ & Cost: $428.7 \mathrm{~kg}$ \\
la Sal & Time: $57.1 \mathrm{~h}$ & Time: $61.1 \mathrm{~h}$ \\
\hline
\end{tabular}

Transport from Cardona to Iulia Lybica would have been relatively straightforward, through modern Berga and the pass at Castellar. Transport to Iulia Lybica from Gerri de la Sal would have been more involved, with part over the watershed between Pallars and the Segre river through modern-day Buseu and Guàrdia d'Ares.

As for the Madriu, the optimum route from Cardona would not have been through the Strata Ceretana, but rather to the south of the Cadí range, through Solsona, Alt Urgell and Sant Julià de Lòria thus avoiding the steep slopes of the pass of Castellar. This fact is an interesting confirmation of the possibility of the existence of a via salaria through Tuixén, that has been documented at the beginning of the modern era. From Gerri, however, the journey to the Madriu would have been slightly shorter, going upriver along the Noguera Pallaresa river to Llavorsí, and then over the Port de Cabús to modern Os de Civís and Andorra.

The time taken for such journeys would not seem excessive, with a 5-6 days' march as a mean. From the stand- point of cost, however, it is clear that the shorter distances would have been preferable. Thus, it would have been advantageous for Iulia Lybica to ensure its imports of salt from Cardona, instead of having them transported from as far west as the Pallars. On the other hand, Madriu in its position further west was clearly a customer for the salt of Gerri. Thus, one could speak of a natural area of influence of each center of production south of the Pyrenees. To the north, the center of salt production at Salies may have played a similar role in the Garonne river valley.

\section{Discussion}

With the results of the computer model in hand, in this section we shall try to see what their significance could be from an economic standpoint and in relation to the general situation of the Roman sphere of influence.

\subsection{Importing products by sea from a distant origin}

Optimum routes for importing goods from other areas of the Pyrenees and from further afar have been calculated previously. If we consider Iulia Lybica as a point in which we have archaeological evidence of various classes of imports, we observe that routes originating in the western section of the Central Pyrenees may arrive in the city either through the Segre river valley and Strata Ceretana, or from the north through Matemale. On the other hand, goods that came from the coast or from further abroad in other regions of the Empire would advantageously have been unloaded at ports such as Barcino for the south, or Ruscino (Perpig- 


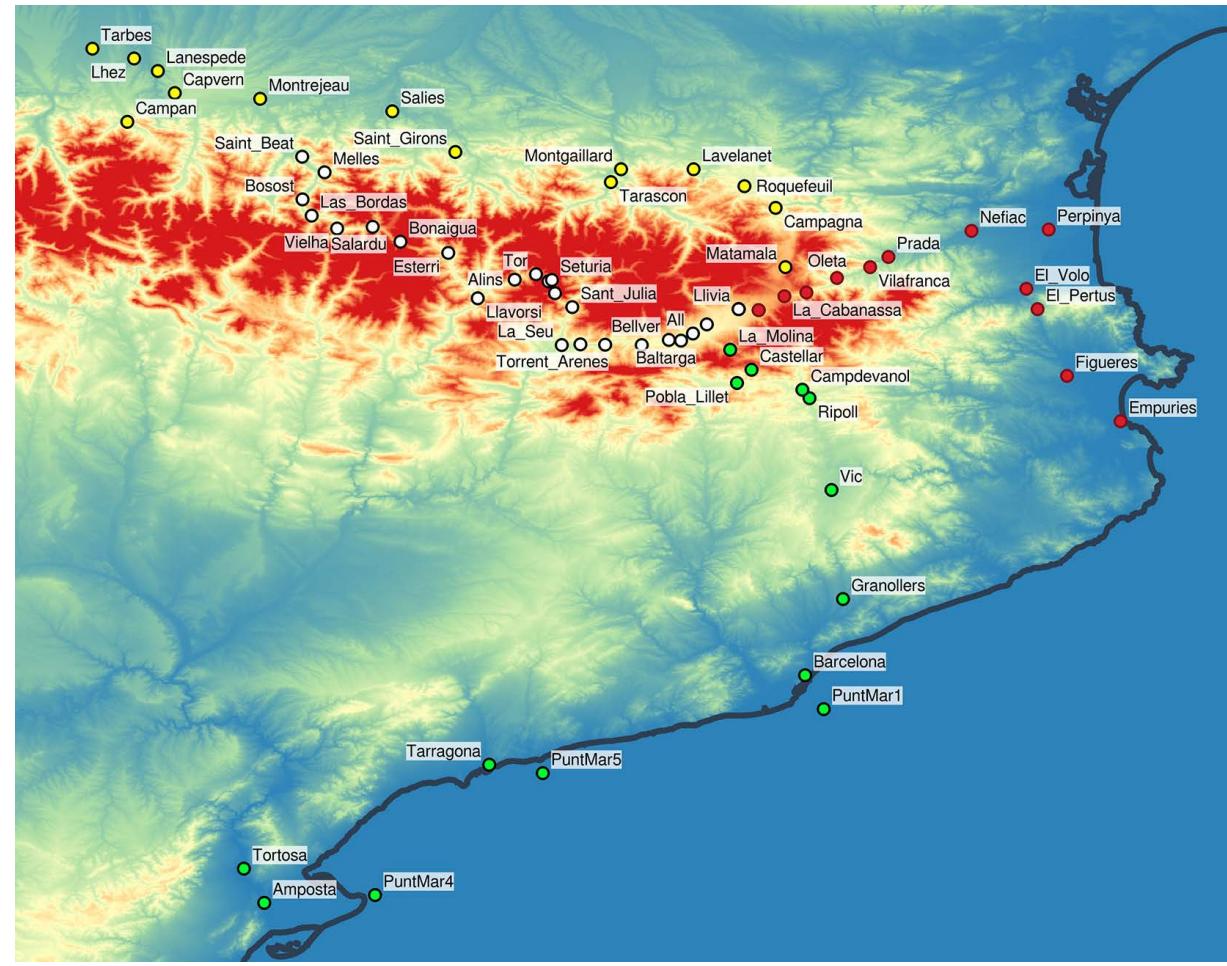

Figure 10. Optimum routes for importing goods to Iulia Lybica.

nan) for the north, and from there transported by land either through Ripoll and the pass at Castellar, or the Tet river valley and Col de la Perche (figure 10).

A prototypical example could perhaps be the fine foodstuffs, comprised of olive oil, olives themselves, wine and garum. Such goods may have been imported - at a certain cost - either for the use of Roman military garrisons in Cerdanya, or for sale to local elites with sufficient spending power and a taste for Roman cuisine. Such goods would certainly have been sources from Baetica, though Tarraconensis may have become an alternative when wine production got sufficiently underway. Let us compare total costs for the journey from their place of origin to Iulia Lybica (table 5):

Table 5. Total cost of transport of foodstuffs, from origin to Iulia Lybica via Barcino

\begin{tabular}{|c|c|c|}
\hline Origin & Tarraconensis & Baetica \\
\hline $\begin{array}{l}\text { Costs from } \\
\text { origin to } \\
\text { Barcino (sea) }\end{array}$ & $\begin{array}{l}9.4 \mathrm{~kg} \text { wheat } \\
/ \text { tonne }\end{array}$ & $\begin{array}{l}130 \mathrm{~kg} \text { wheat } \\
\text { / tonne } \\
(1,300 \mathrm{~km} @ \\
0.1 \mathrm{~kg} / \mathrm{km} / \\
\text { tonne })\end{array}$ \\
\hline $\begin{array}{l}\text { Costs from } \\
\text { Barcino to } \\
\text { Iulia Lybica } \\
\text { (land) }\end{array}$ & $\begin{array}{l}703.8 \mathrm{~kg} \\
\text { wheat / tonne }\end{array}$ & $\begin{array}{l}703.8 \mathrm{~kg} \\
\text { wheat / tonne }\end{array}$ \\
\hline $\begin{array}{l}\text { Total cost of } \\
\text { transport }\end{array}$ & $\begin{array}{l}713.2 \mathrm{~kg} \\
\text { wheat / tonne }\end{array}$ & $\begin{array}{l}833.8 \mathrm{~kg} \\
\text { wheat / tonne }\end{array}$ \\
\hline
\end{tabular}



of the transport of imports and exports

In the same way, wa can calculate the total cost of transport for similar goods imported through the northern port of Ruscino, in this case comparing goods shipped from Baetica with others from Massilia - since it does not seem reasonable to have goods from Taraconensis shipped by sea to Ruscino when a more economical route existed through Barcino (table 6):

Table 6. Total cost of transport of foodstuffs, from origin to Iulia Lybica via Ruscino

\begin{tabular}{|c|c|c|}
\hline Origin & Massilia & Baetica \\
\hline $\begin{array}{l}\text { Costs from } \\
\text { origin to } \\
\text { Ruscino } \\
\text { (sea) }\end{array}$ & $\begin{array}{l}30 \mathrm{~kg} \text { wheat / } \\
\text { tonne } \\
(300 \mathrm{~km} @ \\
0.1 \mathrm{~kg} / \mathrm{km} / \\
\text { tonne) }\end{array}$ & $\begin{array}{l}145 \mathrm{~kg} \text { wheat } / \\
\text { tonne } \\
(1,450 \mathrm{~km} @ \\
0.1 \mathrm{~kg} / \mathrm{km} / \\
\text { tonne })\end{array}$ \\
\hline $\begin{array}{l}\text { Costs from } \\
\text { Ruscino to } \\
\text { Iulia Lybica } \\
\text { (land) }\end{array}$ & $\begin{array}{l}434.5 \mathrm{~kg} \\
\text { wheat / tonne }\end{array}$ & $\begin{array}{l}434.5 \mathrm{~kg} \text { wheat } \\
\text { / tonne }\end{array}$ \\
\hline $\begin{array}{l}\text { Total cost } \\
\text { of transport }\end{array}$ & $\begin{array}{l}464.5 \mathrm{~kg} \\
\text { wheat / tonne }\end{array}$ & $\begin{array}{l}579.5 \mathrm{~kg} \\
\text { wheat / tonne }\end{array}$ \\
\hline
\end{tabular}

It is clear that the cost of land transport far exceeded that of the (much longer) segment previously made by sea. In the case of transport from nearby ports such as Massilia, the cost of the initial segment by sea from Massilia to Ruscino was only $6.5 \%$ in proportion of the total cost of shipment. For more distant origins, such as Baetica, the proportion of sea transport went up, but only to $25 \%$ of the total cost of shipment.

To give some economic significance to these costs expressed in kilograms of wheat, we may use prices from Diocletian's Edict (Prandtl, 2011) to give an idea of relative costs. Since the Edict dates from year 301, such monetary values should be seen merely as indicative of a situation that would have suffered some evolution since our period of interest of the first c. BCE to CE. These prices were:

- Value of wheat: 100 denarii per modius castrense, or a volume of 12.93 liters. Supposing an average density of 760 gr per liter, we get an approximate price of $10.18 \mathrm{den} / \mathrm{kg}$ for wheat.

- Value of first quality wine: 50 denarii per sextarius, or $0.546 \mathrm{~L}$. This gives us $91.97 \mathrm{den} / \mathrm{L}$ for fine wine.

- Value of lesser quality wine: 16 denarii per sextarius, giving 29.30 den/L.

In addition, we may suppose that each tonne transported contained merely $500 \mathrm{~kg}$ of liquid wine, or 500 liters. The remaining weight would have been made up by the containers (amphorae) and packaging. Thus, we obtain, for one tonne transported:

- Cost of transport from Massilia to Iulia Lybica: 4,728.61 den.

- Cost of transport from Baetica to Iulia Lybica: 5,899.31 den.

- Value of wine (if of superior quality): 45,985 den.

- Value of wine (if of lesser quality): 14,650 den.

In all cases, this data confirms that even though the cost of transport made up a large proportion of the value of the wine, importing wine to the Pyrenean region of Cerdanya was still an economically viable proposition, with the additional costs of transport in the 10.28 to $40.26 \%$ of the price of the goods. Moreover, relative importance of the cost of transport would have gone down as its quality - and value - increased, thus making the trans- 

of the transport of imports and exports

port and sale of finer wines a more attractive occupation for a mercator capable of finding customers to sell his wares to.

A further point is that distance is not much of a factor in costs; products imported from further away would simply have been transported by sea over a larger proportion of their route, at a moderate rate of cost. All goods imported by sea, from near or far, would have been impacted mainly by the high cost of the final segment of terrestrial transport from the coast to Cerdanya.

\subsection{Importing products by land}

Perhaps the most striking imports found during excavations at Iulia Lybica were stone architectural elements, such as crustae. For those that seem to have rather distant oriental origins - such as pavonaz$z o$ - the previous discussion on the imports of foodstuffs holds. However, those elements imported from the quarries of Campan and Saint-Béat in the central Pyrenees may merit further analysis. For these, the computational model gives us two possible itineraries:

- The northern route, using river transport on the Garonne, at Salies crossing by terrestrial means over to the Ariège river valley, then through Lavelanet and Matamale to Iulia Lybica. This would seem the most economical option for items with origins in Campan or in proximity Lugdunum Convenarum.

- The southern route, up modern-day Val d'Aran and the Port de la Bonaigua, Llavorsí, up to Alins and Tor and over the Port de Cabús to Andorra and then up along river Segre on the Strata Ceretana.
The southern route has two main difficulties for winter use: the Port de Bonaigua at $2076 \mathrm{~m}$ a.s.l., and Port de Cabús at $2328 \mathrm{~m}$. For this reason, we suppose transport - especially of heavy items such as stone blocks - over this route could only have been envisioned during those parts of the year when the passes are clear of snow: summer and fall.

As for the northern route, the use of river transport implies the need to take variations in water flow into account. Additionally, modern water management using barrages and the use of rivers to produce electricity was obviously not of help during Roman times. More precisely, it would seem that snow melt during spring (April and May) would have lead to excessive water flow, making river transport dangerous if at all possible. Also, flow during fall and winter may have been variable, with periods of insufficient water depth to permit the passage of heavily-laden vessels. Thus, a Roman mercator needing to transport stone elements from Pyrenean quarries to Iulia Lybica would have needed to take into account not only the question of economic cost (and duration) of each route, but also the time of year during which transport was desired. Integrating these elements together, we obtain table 7.

In the first place, it is noticeable that the transport of heavy goods would need to be done in summer or fall. This close connection between transport and seasons is typical of mountain contexts, as it is for sea navigation in the Mediterranean. No doubt the cycles of production and expedition of stone items would have been managed in Roman times with this factor in mind.

In second place, it is clear that the northern route is preferable over the south- 
Table 7. Comparison of possible routes from quarries in the central Pyrenees to Iulia Lybica

\begin{tabular}{|c|c|c|c|}
\hline & Season & From Saint-Béat & $\begin{array}{l}\text { From Lugdunum } \\
\text { Convenarum }\end{array}$ \\
\hline \multirow{4}{*}{$\begin{array}{l}\text { Northern route } \\
\text { (Garonne, } \\
\text { Lavelanet, } \\
\text { Matamale) }\end{array}$} & $\begin{array}{l}\text { Winter: closed, due to } \\
\text { lack of water flow }\end{array}$ & \multirow{4}{*}{$\begin{array}{l}\text { Cost: } 741.8 \mathrm{~kg} \text { of } \\
\text { wheat / tonne } \\
\text { Time: } 115.0 \text { hours }\end{array}$} & \multirow{4}{*}{$\begin{array}{l}\text { Cost: } 736.4 \mathrm{~kg} \text { of wheat } \\
\text { / tonne } \\
\text { Time: } 108.5 \text { hours }\end{array}$} \\
\hline & $\begin{array}{l}\text { Spring: closed, due to } \\
\text { excess water flow }\end{array}$ & & \\
\hline & Summer: open & & \\
\hline & Fall: open & & \\
\hline \multirow{4}{*}{$\begin{array}{l}\text { Southern route } \\
\text { (Port de la } \\
\text { Bonaigua, Port } \\
\text { de Cabús) }\end{array}$} & $\begin{array}{l}\text { Winter: closed, due to } \\
\text { excessive snow }\end{array}$ & \multirow{4}{*}{$\begin{array}{l}\text { Cost: } 877.5 \mathrm{~kg} \text { of } \\
\text { wheat / tonne } \\
\text { Time: } 127.6 \text { hours }\end{array}$} & \multirow{4}{*}{$\begin{array}{l}\text { Cost: } 888.3 \mathrm{~kg} \text { of wheat } \\
\text { / tonne } \\
\text { Time: } 154.7 \text { hours }\end{array}$} \\
\hline & $\begin{array}{l}\text { Spring: closed, due to } \\
\text { excessive snow }\end{array}$ & & \\
\hline & Summer: open & & \\
\hline & Fall: open & & \\
\hline
\end{tabular}

ern, both from the standpoint of cost and that of travel time. This may not come as a surprise, due to the possibility of the use of water transport on rivers over, at least, part of the journey. It should be stressed, however, that this does not exclude entirely the possibility of the southern route being used. In cases where the transporter would have needed to make partial deliveries en route at places along the southern route, this choice would not have incurred excessive overheads in cost or delays. The same reasoning would apply to the transport of lighter items, where perhaps the use of pack animals throughout could have been an expedient solution avoiding altogether the transfer of goods from one means of transport to another.

Finally, regarding the question of imports of salt from neighboring regions (Gerri de la Sal, or Cardona), it may be useful to remember that salt, though a necessity for any pastoral activity and also for the preparation of cheese or salted meat, was not an excessively expensive commodity during Roman times. The Edict on Prices of Diocletian (Prantl, 2011) quotes a maximum price for salt at 100 denarii per modius castrense, precisely the same value as for wheat and largely less than that of wine or other foodstuffs. For this reason, we may suppose that the choice of origin of the salt would have been extremely sensitive to the cost of transport. The choice of shorter and more economic routes would have lead to a clear delimitation of the areas of influence of each source of salt. A line of separation between areas supplied by Gerri and those by Cardona would have run across the Urgell plain in the proximity of modern Martinet, with western regions supplied from the Pallars and eastern from Cardona.

\subsection{Exports of local products}

The Cerdanya region and Iulia Lybica would have had up to four main options for exporting local produce, thus illus- 
trating its situation at a main crossroads in the eastern Pyrenees:

- North, overland to the Ariège and Garonne river valleys, and from there to southern Gaul.

- West, along the Strata Ceretana to Urgell, then south Ilerda and further south along river Ebro.

- South, across the Castellar pass to Berga, then continuing overland to Barcino.

- East, to the sea ports at Ruscino or Narbo.

The costs associated with some of these possibilities are laid out in table 8 .

It is noteworthy that, whenever river transport is used, the associated costs are different in each direction. Thus, related to our previous discussion on importing goods from the region Lugdunum Convenarum in which the northern route appeared as a more economical option both for cost and for travel time, now when traveling from east to west the northern route may still be considered the more economical option for cost, but is now longer than that through the Pallars and Val d'Aran. This is due to the use of the Garonne, now in the upriver direction. As a consequence, the route through $\mathrm{Val}$ d'Aran would have shown some attraction to those needing speedy transport, perhaps a factor to take into account for the exports of perishable foodstuffs such as cheese, and certainly so for commercial or military correspondence.

Furthermore, the route running along modern Route Nationale 20 through Porta and Hospitalet would become a rather interesting possibility in the east-west direction, though not when importing goods to Iulia Lybica from the west - since the Lavelanet section has both less slope and economic cost.

As for transport toward a sea port, Ruscino is a clear winner in terms of lesser cost over the overland - and most expensive - section of the itinerary. Exports through Dertosa or Barcino would not have been viable from the standpoint of costs, and would also have incurred more lengthy transport duration. It is interesting, though, that in the north-south direction the route though Ilerda and using the Ebro river is a more economical choice than through Barcino, contrary to the situation when importing goods into the Cerdanya region.

This increased cost may not have been an impediment to exporting select produce from Iulia Lybica to other regions of the Empire. To take a complete example, let us calculate the costs of transport of an item such as pernae ceretanae, from Iulia Lybica to two different destinations: Baetica on the western edge of the Roman Europe, and Rome itself as a reasonable point of sale of such produce (table 9).

For both final destinations, the cost of transport for the land segment of their itinerary constitutes, as for imports, the larger part of the total cost of transport. This result may be turned around, and interpreted to indicate that the location of the final destination has no major influence on the cost of transport, naturally with the condition that this final destination may be reached using sea transport. Thus, exporting pernae ceretanae to Rome, Baetica or any other sea port on the Roman Mediterranean would have had a similar breakdown of costs.

Maximum values given in Diocletian's Edict on Prices give us the following information: 

of the transport of imports and exports

- Value of wheat: 100 denarii per modius castrense (or $12.93 \mathrm{~L}$ ). If we use an average density of $760 \mathrm{~g} / \mathrm{L}$ for wheat, we obtain an approximate value of $10.18 \mathrm{den} / \mathrm{kg}$ of wheat.

- Value of pernae (of high quality): 20 denarii per pondus italicus (a measure of weight of $328 \mathrm{~g}$ ), which gives us an approximate value of $60.97 \mathrm{den} /$ $\mathrm{kg}$ of salted ham.

Applying these prices to the transport of one tonne of pernae from Iulia Lybica to Ostia, we see that the goods themselves would have been worth some 60,970 denarii, while transport would

Table 8. Comparison of possible routes for exports from Iulia Lybica

\begin{tabular}{|c|c|c|}
\hline $\begin{array}{l}\text { Destination, from Iulia } \\
\text { Lybica }\end{array}$ & Season & Cost and time \\
\hline $\begin{array}{l}\text { Lugdunum Convenarum } \\
\text { (via Lavelanet and river } \\
\text { Garonne) }\end{array}$ & $\begin{array}{l}\text { Winter: closed, due to excessive snow } \\
\text { Spring: closed, due to excess water flow } \\
\text { Summer: open } \\
\text { Fall: open }\end{array}$ & $\begin{array}{l}\text { Cost: } 621.0 \text { kg of wheat / } \\
\text { tonne } \\
\text { Time: } 156.9 \text { hours }\end{array}$ \\
\hline $\begin{array}{l}\text { Lugdunum Convenarum } \\
\text { (via Port de Cabús, Port } \\
\text { de la Bonaigua and Val } \\
\text { d'Aran) }\end{array}$ & $\begin{array}{l}\text { Winter: closed, due to excessive snow } \\
\text { Spring: closed, due to excessive snow } \\
\text { Summer: open } \\
\text { Fall: open }\end{array}$ & $\begin{array}{l}\text { Cost: } 882.9 \mathrm{~kg} \text { of wheat / } \\
\text { tonne } \\
\text { Time: } 134.1 \text { hours }\end{array}$ \\
\hline $\begin{array}{l}\text { Lugdunum Convenarum } \\
\text { (via Porta, Hospitalet, } \\
\text { Tarascon) }\end{array}$ & $\begin{array}{l}\text { Winter: closed, due to excessive snow } \\
\text { Spring: closed, due to excess water flow } \\
\text { Summer: open } \\
\text { Fall: open }\end{array}$ & $\begin{array}{l}\text { Cost: } 562.3 \mathrm{~kg} \text { of wheat / } \\
\text { tonne } \\
\text { Time: } 143.3 \text { hours }\end{array}$ \\
\hline $\begin{array}{l}\text { Ruscino (via Col de la } \\
\text { Perche) }\end{array}$ & $\begin{array}{l}\text { Winter: closed, due to excessive snow } \\
\text { Spring: open } \\
\text { Summer: open } \\
\text { Fall: open }\end{array}$ & $\begin{array}{l}\text { Cost: } 434.5 \mathrm{~kg} \text { of wheat / } \\
\text { tonne } \\
\text { Time: } 44.2 \text { hours }\end{array}$ \\
\hline $\begin{array}{l}\text { Dertosa (via Barcino and } \\
\text { by sea) }\end{array}$ & $\begin{array}{l}\text { Winter: open } \\
\text { Spring: open } \\
\text { Summer: open } \\
\text { Fall: open }\end{array}$ & $\begin{array}{l}\text { Cost: } 728.9 \mathrm{~kg} \text { of wheat / } \\
\text { tonne } \\
\text { Time: } 152.4 \text { hours }\end{array}$ \\
\hline $\begin{array}{l}\text { Dertosa (via Strata } \\
\text { Ceretana, river Ebro) }\end{array}$ & $\begin{array}{l}\text { Winter: closed (?), due to insufficient } \\
\text { water } \\
\text { Spring: closed, due to excess water flow } \\
\text { Summer: open } \\
\text { Fall: open }\end{array}$ & $\begin{array}{l}\text { Cost: } 748.0 \mathrm{~kg} \text { of wheat / } \\
\text { tonne } \\
\text { Time: } 133.5 \text { hours }\end{array}$ \\
\hline
\end{tabular}


Table 9. Comparison of transport costs for exports of pernae ceretanae from Iulia Lybica

\begin{tabular}{|c|c|c|}
\hline Destination & Ostia (Roma) & Baetica \\
\hline $\begin{array}{l}\text { From Iulia Lybica to } \\
\text { Ruscino }\end{array}$ & $\begin{array}{l}434.5 \mathrm{~kg} \text { of wheat / tonne } \\
\text { (computational model) } \\
79.8 \% \text { of total cost of transport }\end{array}$ & $\begin{array}{l}434.5 \mathrm{~kg} \text { of wheat / tonne } \\
\text { (computational model) } \\
75 \% \text { of total cost of transport }\end{array}$ \\
\hline $\begin{array}{l}\text { From Ruscino to the } \\
\text { final destination }\end{array}$ & $\begin{array}{l}110 \mathrm{~kg} \text { of wheat / tonne } \\
(1100 \mathrm{~km} @ 0.1 \mathrm{~kg} / \mathrm{km} / \text { tonne }) \\
20.2 \% \text { of total cost of transport }\end{array}$ & $\begin{array}{l}145 \mathrm{~kg} \text { of wheat / tonne } \\
(1450 \mathrm{~km} @ 0.1 \mathrm{~kg} / \mathrm{km} / \text { tonne }) \\
25 \% \text { of total cost of transport }\end{array}$ \\
\hline Total cost of transport & $544.5 \mathrm{~kg}$ of wheat / tonne & $579.5 \mathrm{~kg}$ of wheat / tonne \\
\hline
\end{tabular}

have cost 5.543 denarii, a mere $9 \%$ over the value of the goods themselves. This seems a reasonable amount, and which can be favorably compared to other costs such as the taxes levied on the transaction, both portoria payable on the transport of goods from Hispania Citerior province to Gallia Narbonensis (2.5\% on the value of the goods), and import duties levied on entry to port at Ostia.

A similar reasoning may be applied to similar goods of some value, such as cheese. Other products of pastoral and forestry activities may have been in different circumstances, due to varying values in relationship to weight and ease of transport. Thus, wood may or may not have been a product of some economic interest for exportation, depending on the availability of river transport to decrease its cost of transport. On the other hand, pine pitch may have had some use outside of the Pyrenean region. Extraction of pitch is a somewhat involved process that requires both time and effort, thus increasing its value. On the other hand, as a finished product, pitch is more compact and easier to transport than the wood it is made from. Unfortunately, our lack of knowledge on the precise demand for pitch in Roman times, and the prices it commanded, does not allow us to propose a complete cost analysis of pitch exported from Cerdanya to, for instance, the region of Tarraconensis or that of Massilia in Southern Gaul. Here, such pitch could have been of use both for ship hull caulking and as an agent to make containers impermeable, though we are at the mercy of further investigation to obtain hard data to better base such speculation.

Finally, there is a particular category of goods that may have been exported from this region during Roman times, as they were continuously during the Medieval period and modern times. It consists of livestock, mainly equidae such as donkeys and mules. These would have been of some interest for Roman military purposes as pack animals, and also for commercial uses. Moreover, transport costs could have been kept to a minimum, basically covering only the cost of feed for the animals and food for their drivers. However, though we may see this export as likely in the general context of agropastoral activity in the Pyrenees, little archaeological evidence has been obtained to justify such as supposition.

\section{Conclusions and further remarks}

In this work, a computer model of the transport network of Roman times in the eastern Pyrenees and surrounding ar- 

of the transport of imports and exports

eas was drawn up. Together with a mathematical model of speeds and costs of different means of transport taking into account slope for land transport, and direction of movement for river vessels, these tools were used to determine optimum itineraries to import into the area of interest goods originating both from the Mediterranean coast and from areas further inland, and also for the export of goods from the Cerdanya region to other parts of the Roman sphere of interest. In all cases, transport cost profiles were drawn up, to assess the importance of cost and journey time in the mountainous area with its characteristics on the economic feasibility of such transports.

It was found that optimal routes for imports from the southern and western Mediterranean used sea transport to the port of Barcino, and then land transport northwards through modern-day Berga to their destination at Iulia Lybica. From southern Gaul and the eastern Mediterranean, the port of Ruscino and land transport over the Col de la Perche seem a better alternative, while from the central Pyrenees the transport of stone elements would have used the Garonne river and then land transport through Lavelanet and Matamale. Exports would not necessarily have traced the same routes, using river transport for economy where possible (for example: the Ebro river), though the port of Ruscino would still have played a major role.

Cost analysis of the imports of foodstuffs such as fine wine show that the cost of transport is concentrated within the overland segment from the seaport to Cerdanya, while sea transport in general plays a much smaller role. Thus, the cost of transport to Iulia Lybica and its neighboring region is much greater than would have been the case for other cities in the Empire. The total cost of transport would nevertheless be a small part of the value of the wine itself, at about $10 \%$ for fine wine and up to $40 \%$ for lesser quality.

Importing goods such as construction stone items from the central Pyrenees would also have been cost-effective, though comparable to that of their transport from other regions of the Roman world (at 700 to $800 \mathrm{~kg}$ of wheat per tonne of goods). Weather conditions over high mountain passes (such as Port de la Bonaigua) in winter, and fluctuating water levels in rivers in spring would have restricted such transport from $\mathrm{Lug}$ dunum Convenarum or nearby area to summer or fall.

Finally, exporting products such as pernae ceretanae (salt ham) to places such as Rome itself would have made perfect economic sense, largely due to their value as goods. Exports of other merchandise would have depended on access to river transport for economic transport (for wood), and the market willing to absorb products such as pitch (perhaps in Tarraconense, or the Massilia region).

Overall, it is clear that transport over mountain terrain, with varying degrees of slope, lesser roads or mountain paths, and more stringent weather conditions would have cost more than the equivalent distance over the plains. That being said, the main factor involved in creating supplementary expense in the Andorra-Cerdanya region in the eastern Pyrenees is not the slope, but the lack of sea transport within the area. Thus, river transport where available (to the north-west and southwest), and access to sea transport from the ports of Barcino and - specially - Ruscino would have played a major role in decreasing the cost of transport. It is 
striking that, even though transport did play a major role in the cost structure of goods both imported into and exported from the region, commercial activities involving merchandise of high quality (and cost) would still have been possible from an economic standpoint. In this sense, the traditional view of a mountain range such as the Pyrenees as an impediment to commercial activities is not validated.

Techniques developed in this project do not make suppositions on the nature of the terrain, but are flexible and may be adapted to various physical circumstances: other means of transport or new types of via may be introduced as necessary. Since the Pyrenees was by no means the only mountain range situated within the territory controlled by Rome, it is envisaged that studies along similar lines may be undertaken on areas such as the coastal ranges along the southern and western Iberian peninsula, considering in particular the role of the Guadalquivir and Tajo rivers in making inland regions accessible to Roman influence and economic use, such as mining. Other regions of interest may include mountain ranges in the Alps and across the Balkans, and their influence on access to the limes along the Danube river from the center of Rome's military and economic power, among others.

\section{Bibliographical references}

Campillo, J.; Borràs, H. (1996). «Noves dades sobre Iulia Lybica (Llívia, Cerdanya) a partir de la revisió dels materials». Cypsela, 11, 99-103.

Campillo, J.; Mercadal, O. (1997). «El paper de la Cerdanya en les relacions transpirinenques en època antiga». Annals de l'Institut d'Estudis Gironins, 37, 875-895.

Canturri, P.; Llovera, X.; Roca, AM.; Guillamet, J. (1985). «Des outils de pierre aux monnaies romaines. Méconnu: le domaine archéologique d'Andorre». Histoire et Archéologie, 96, 65-68.

Capelli, C.; Contino, A.; Djaoui, D.; Rizzo, G. (2017). «Anfore neo-puniche del I secolo d.C. di Arles, Ostia e Roma: classificazione tipo-petrografica, origine e diffusione». The Journal of Fasti Online, 391, 1-43.

CARRERAS, C. (1994). Una reconstrucción del comercio en cerámicas: la red de transportes en Britannia. Cuadernos de Arqueología, 7. Ampurias: Edicions Servei del Llibre l'Estaquirot.

Carreras, C.; Soto, P. (2010). Historia de la movilidad en la Peninsula Ibérica: Redes de transporte en SIG. Barcelona: Editorial Universitat Oberta de Catalunya.

Carreras, C.; Gù̀rdia, J.; Guitart, J.; Olesti, O. (2014). «Prospecció geofísica i sondejos al fòrum de Iulia Lybica». In: XII Jornades d'arqueologia de les Comarques de Girona. Besalú: Universitat de Girona. Besalú, 253-260.

Dicks, T.R.B. (1972). «Network analysis and historical geography». Area, 4, 4-9.

Dijkstra, E. W. (1959). "A note on two problems in connection with graphs». Numerische Mathematik, 1, 269-271.

Esmond-Cleary, S. (2008). Rome in the Pyrenees. Lugdunum and the Convenae, from the First Century B.C. to the Seventh Century A.D. New York: Routledge Monographs in Classical Studies, New York. 
Fonte, J.; Parcero-Oubiña, C.; Costa-García, J-M. (2017). «A GIS-based analysis of the of the rationale behind Roman roads. The case of the so-caled Via XVII (NW Iberian Peninsula)». Mediterranean Archeology and Archaeometry, 17 (3), 163-189.

Gascón, C. (2013). «Estudi documental de l'activitat metal.lúrgica a la vall de Vansa». In: PALET, J.M. (ed.). Memòria de la intervenció arqueològica al jaciment de Cemeres (Josa i Tixén, Alt Urgell). Barcelona: Generalitat de Catalunya, Departament de Cultura i Mitjans de Comunicació, 7035, 30-39.

Gassiot, E.; Clemente, I. (2018). «Unes muntanyes amb gent, ramats i camps: els Pirineus catalans al neolític». In: Remolins, G.; Gibaja, J. (eds.). Les Valls d'Andorra durant el Neolitic: un encreuament de camins al centre dels Pirineus. Barcelona: Museu d'Arqueologia de Catalunya.

Griffiths, D. (2013). Augustus and the Roman provinces of Iberia, doctoral dissertation. Liverpool: University of Liverpool.

Guàrdia, J.; Carreras, C.; De Soto, P. (2017). «Circuits comercials a Iulia Lybica (Llívia): visions a partir de les ceràmiques i els marbres». Revista d'arqueologia de Ponent, 27, 147-168. <https://doi.org/10.21001/rap.2017.27.6>

Gù̀rdia, J.; Carreras, C.; Guitart, J.; Olesti, O. (2017). El Fòrum de Iulia Lybica i la capacitat ceretana en època altmedieval: novetats arqueològiques. Treballs d'Arqueologia, 21, 181 204. <https://doi.org/10.5565/rev/tda.62>

Gù̀rdia, J. (2018). El forum romà de Iulia Lybica i l'arqueologia urbana de Llivia (Cerdanya). Doctoral dissertation. Universitat Autònoma de Barcelona.

Herzog, I. (2013). «The Potential and Limits of Optimal Path Analysis». In: Bevan, A.; Lake, M. (eds.). Computational Approaches to Archaeological Spaces. Walnut Creek: Left Coast Press: $179-211$.

Lanz, J. (2017). Dinámicas de enfrentamiento, colaboración y resolución de conflictos en el entorno circumpirenaico occidental (II aC - VII $d C$ ). Doctoral dissertation. Bilbao: Universidad del País Vasco.

Marlier, S. (2014). «Arles-Rhône 3, un Chaland Gallo Romain du Ier Siècle après Jesus-Christ». Archaeonautica, 18/2014, 330-337. Parid: CNRS editions. <https://doi.org/10.1111/1095-9270.12167>

Martínez, P.; Vidal, A.; Fortó, A.; Turu, V. (2016). «Els punxons de Juberri. En Comunitats agrícoles al Pirineu: l'ocupació humana a Juberri durant la segona meitat del Vè mil.lenni cal AC (Feixa del Moro, Camp del Colomer i Carrer Llinàs 28, Andorra)». Monografies del Patrimoni Cultural d'Andorra, 6, 193-200.

Morera, J.; Mercadal, O.; Olesti, O.; Crespo, C. (2010). «El Castellot de Bolvir (Cerdanya): ocupacions ceretana, iberorromana i altmedieval». Tribuna d'arqueologia 2009-2010, 295-329.

Morera, J. (2017). Territori i poblament de Cerdanya a l'antiguitat. La iberització i la romanització de la vall cerdana. Doctoral dissertation. Barcelona: Universitat Autònoma de Barcelona.

Muñoz, A. (2018). Anàlisi de rutes de mínim cost (LCP) aplicada al cas de l'avanç del contingent cartaginès d'Anníbal Barca durant l'etapa catalana-Pirenaica. Treball de final de grau (Arqueologia). Barcelona: Universitat Autònoma de Barcelona.

Olesti, O. (2017). «Augusto y el control de los territorios pirenaicos». Gerión, 35, 163-190. $<$ https://doi.org/10.5209/GERI.56143>

Olesti, O.; Mercadal, O. (2017). «L'explotació dels territoris pirinencs orientals en època antiga (s. VI-I ane)». Treballs d'arqueologia, 21, 9-47. $<$ https://doi.org/10.5565/rev/tda.69>

Orengo, H.A.; Palet, J.M.; Ejarques, A.; Miras, Y.; Riera, S. (2013). «Pitch production during the Roman period: an intensive mountain industry for a globalised economy?». Antiquity, 87 (337), 802-814. 

of the transport of imports and exports

Palet, J.M.; Ejarque, A.; Miras, Y.; Riera, S.; Euba, I.; Orengo, H. (2006). «Formes d'ocupació d'alta muntanya a la vall de la Vansa (Serra del Cadí - Alt Urgell) i a la vall del Madriu-Perafita-Claror (Andorra): estudi diacrònic de paisatges culturals pirinencs». Tribuna d'Arqueologia, 2006, 229-253.

Palet, J.M.; Molsosa, A.G.; Romeu, H.A.; Alamino, T.P. (2017). «Els espais altimontans pirenaics orientals a l'Antiguitat: 10 anys d'estudis en arqueologia del paisatge del GIAP-ICAC». Treballs d'Arqueologia, 21, 77-97. $<$ https://doi.org/10.5565/rev/tda.59>

Peña-Chocarro, L.; Zapata, L. (2005). «Trade and new plant foods in the western Atlantic coast: the Roman port of Irun (Basque Country)». In: Urteaga, M.; Noain, M.J. (eds.). Mare Exterior. El Occidente Atlántico en época Romana. Roma: Escuela Española de Historia y Arqueologia en Roma-CSIC, 169-178.

Polybius, Histories. Specially: Liber III, epigraph 35 and ff.

Prantl, M. (2011). «Diocletian's Edict on Maximum Prices of 301 AD: a fragment found in Aigeira». Historia scriber, 3, 359-397.

Rébé, I.; RodÀ de Llanza, I.; Pensabene, P. (2009). «The marmara from the forum of Ruscino». In: Gutierrez García, A.; Lapuente, P.; RodÀ de Llanza, I. (eds.). Interdisciplinary Studies on Ancient Stone. Proceedings of the IX ASMOSIA Conference, Tarragona: Institut Català d'Arqueologia Clàssica, 113-116.

ScheIDEL, W. (2015). «ORBIS: the Standford geospatial network model of the Roman World». Princeton/Stanford Working Papers in Classics. Standford: Standford University, 1-12. $<$ https://doi.org/10.13140/rg.2.1.2456.9768>

Soto, P. (2011). «SIG y Network Analysis en el estudio de las redes de comunicación de la Cataluña romana». Anejos de AEspA, 59, 651-664.

Soto, P.; Carreras, C. (2006). «Anàlisi de la xarxa de transport a la Catalunya romana: alguns apunts». Revista d'arqueologia de Ponent, 16, 177-191. 
